Review

\title{
Overview of Human HtrA Family Proteases and Their Distinctive Physiological Roles and Unique Involvement in Diseases, Especially Cancer and Pregnancy Complications
}

\author{
Yao Wang and Guiying Nie *(i)
}

Citation: Wang, Y.; Nie, G. Overview of Human HtrA Family Proteases and Their Distinctive Physiological Roles and Unique Involvement in Diseases, Especially Cancer and Pregnancy Complications. Int. J. Mol. Sci. 2021, 22, 10756. https://doi.org/10.3390/ ijms221910756

Academic Editor: Vito Turk

Received: 17 August 2021

Accepted: 2 October 2021

Published: 6 October 2021

Publisher's Note: MDPI stays neutral with regard to jurisdictional claims in published maps and institutional affiliations.

Copyright: (c) 2021 by the authors. Licensee MDPI, Basel, Switzerland. This article is an open access article distributed under the terms and conditions of the Creative Commons Attribution (CC BY) license (https:/ / creativecommons.org/licenses/by/ $4.0 /)$.
Implantation and Pregnancy Research Laboratory, School of Health and Biomedical Sciences, RMIT University, Bundoora, VIC 3083, Australia; yao.wang2@rmit.edu.au

* Correspondence: guiying.nie@rmit.edu.au; Tel.: +61-3-9925-7274

\begin{abstract}
The mammalian high temperature requirement A (HtrA) proteins are a family of evolutionarily conserved serine proteases, consisting of four homologs (HtrA1-4) that are involved in many cellular processes such as growth, unfolded protein stress response and programmed cell death. In humans, while HtrA1, 2 and 3 are widely expressed in multiple tissues with variable levels, HtrA4 expression is largely restricted to the placenta with the protein released into maternal circulation during pregnancy. This limited expression sets HtrA4 apart from the rest of the family. All four HtrAs are active proteases, and their specific cellular and physiological roles depend on tissue type. The dysregulation of HtrAs has been implicated in many human diseases such as cancer, arthritis, neurogenerative ailments and reproductive disorders. This review first discusses HtrAs broadly and then focuses on the current knowledge of key molecular characteristics of individual human HtrAs, their similarities and differences and their reported physiological functions. HtrAs in other species are also briefly mentioned in the context of understanding the human HtrAs. It then reviews the distinctive involvement of each HtrA in various human diseases, especially cancer and pregnancy complications. It is noteworthy that HtrA4 expression has not yet been reported in any primary tumour samples, suggesting an unlikely involvement of this HtrA in cancer. Collectively, we accentuate that a better understanding of tissue-specific regulation and distinctive physiological and pathological roles of each HtrA will improve our knowledge of many processes that are critical for human health.
\end{abstract}

Keywords: HtrA1; HtrA2; HtrA3; HtrA4; cancer; pregnancy; preeclampsia

\section{Introduction}

The high temperature requirement $\mathrm{A}(\mathrm{H} \operatorname{tr} \mathrm{A})$ proteins are a family of evolutionarily conserved serine proteases that are found in a large number of organisms ranging from prokaryotes, yeasts, and fungi to plants, birds, fish, and mammals [1,2]. A unique feature of HtrAs is the presence of a trypsin-like protease domain in combination with one or more C-terminal domains called PDZ [postsynaptic density protein 95 kDa (PSD95), Drosophila disc large tumour suppressor (Dlg1) and zonula occludens-1 (ZO-1)] [2]. PDZ is a structural motif found in many signalling proteins and is known to participate in protein-protein interactions [3]. The PDZ domain in prokaryotic HtrAs facilitates substrate binding and regulates oligomer assembly, cellular localization, and protease activities [2]. According to the current MEROPS database, HtrA proteases belong to the C subfamily of the S1 family peptidases (chymotrypsin) within the PA clan, with the catalytic triad composed of histidine, aspartate and serine residues. The protein DegP (degradation of extracellular proteins) from Escherichia coli is the first HtrA identified, which is characterised to be an ATPindependent serine protease with heat shock-induced proteolytic activities and a chaperone function [4,5]. To date, over $180 \mathrm{HtrAs}$ have been found across prokaryotic and eukaryotic organisms [6]; in general, they play a key role in protein quality control by recognising 
the severely mis-folded/damaged proteins and targeting them for degradation, and many but not all also function as chaperones [1]. The chaperone activity of HtrA/DegP involves multimer oligomerisation to form a cage-like structure, which facilitates the packaging and internalisation of mis-folded proteins to partition them between refolding vs degradation pathways [7]. HtrA/DegP can switch between the two pathways to determine whether a misfolded/unfolded protein can be rescued or degraded, thus promoting protein stability and homeostasis [8,9].

Prokaryotic HtrAs play an essential role in bacterial virulence and survival under cellular or environmental stress [10-15]. Plant HtrAs maintain the photosynthetic machinery by acting as a chaperone in the assembly of photosystem II and as a protease in the degradation of photo-damaged reaction centres [2]. In mammals, four HtrA homologs (HtrA1-4) have been identified across many species, and they participate in various cellular processes, such as cell growth, unfolded stress response, programmed cell death and aging $[1,2,16]$. The dysregulation of HtrAs has been implicated in diverse pathological processes, such as cancer, neurogenerative disorders, arthritic disease and reproductive disorders [17-24]. A recent review has summarised the current understanding of human HtrAs and their activation mechanisms from a structural perspective [16]. Here, we discuss up-to-date knowledge of the four human HtrAs regarding their key molecular characteristics, tissue distribution, potential substrates and distinctive implications in various human diseases especially cancer and pregnancy complications. Animal studies will also be discussed whenever appropriate.

\section{Protein Domain Architecture, Tissue Distribution and Key Molecular Characteristics of Human HtrAs}

\subsection{Domain Architecture}

All four human HtrAs contain the signature motif of a HtrA, a chymotrypsin-like serine protease domain and a C-terminal PDZ domain (Figure 1) [25]. However, their $\mathrm{N}$-terminal organisation differs considerably, naturally separating the family into two distinctive groups (Figure 1A). While the N-terminal region of HtrA1, HtrA3 and HtrA4 contains a putative signal peptide, an insulin-like growth factor binding protein (IGFBP) domain and a kazal protease inhibitor domain [25], that of HtrA2 is entirely different, encompassing a transient peptide and a transmembrane domain (Figure 1A) [26]. Deviations from the above basic domain organisation, resulting from alternative mRNA splicing or post-translational modifications, have been reported or inferred for HtrA1, 2 and 3 [16]. For instance, a shorter isoform of HtrA3 lacking the PDZ domain is expressed in the human endometrium and placenta, and a similar mRNA alternative splicing has been reported for HtrA3 in other species such as the mouse and rat [26-28]. Alternative splicing will be discussed in the subsequent molecular characteristics section.

The domain architecture of human HtrA2 resembles that of bacterial HtrA protein DegS [16], whereas the N-terminal IGFBP-Kazal tandem module present in HtrA1, 3 and 4 is a new addition [16]. It is noteworthy that the IGFBP-Kazal tandem is exclusively found in these HtrAs and another three mammalian proteins (Mac25, Kazal D1, IGFBPL1) [29]. These differences suggest that HtrA1, 3 and 4 may have evolved to fulfil more mammalian specific cellular and physiological functions, whereas HtrA2 may have retained certain features of the ancient HtrAs. Indeed, studies suggest that although all four human HtrAs are active proteases and all form a trimeric or higher oligomeric assembly as prokaryotic HtrAs (Figure 1B), the regulation of oligomerisation and protease activity of HtrA2 resembles that of prokaryotic HtrAs, whereas that of HtrA1, 3 and 4 is distinctly different [16]. For instance, the PDZ domain of HtrA2 critically mediates its proteolytic activity, whereas HtrA1 and HtrA3 are active without the PDZ domain [16]. It remains to be elucidated how the unique N-terminal IGFBP-Kazal tandem influences the physiological functions of HtrA1, 3 and 4 . To date, a structural and functional analysis has found no evidence that these modules in HtrA1 retain their prototypic functions-the IGFBP region neither binds to IGFs nor behaves like an IGFBP, and the Kazal-like segment does not affect the HtrA1 proteolytic activity as would be expected of a protease inhibitor [29]. 
A

HtrA1 (480 aa) HtrA3 (453 aa) HtrA4 (476 aa)

HtrA2 (458 aa)
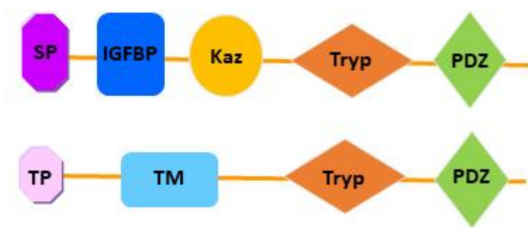

B

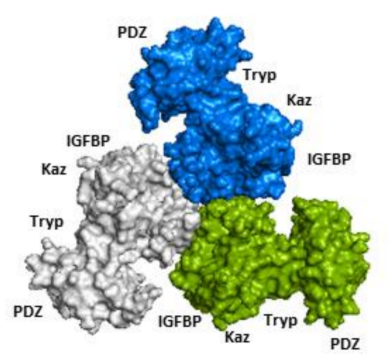

Figure 1. Schematic illustration of protein domain organisation of the four human HtrAs. (A) The distinctive N-terminal region of HtrA2 compared to the other three HtrAs; (B) The predicted trimeric form of HtrA3 (Adapted from Singh, et al., 2014) [25]. SP, signal peptide; IGFBP, insulin growth factor binding protein domain; Kaz, Kazal-type S protease inhibitor domain; Tryp, trypsin-like serine protease domain; PDZ, postsynaptic density protein 95, Drosophila disc large tumour suppressor and zonula occludens-1 domain; TP, transient peptide; TM, transmembrane domain; aa, amino acid.

\subsection{Tissue Distribution}

The four HtrAs have distinctive tissue expression in the human body (Figure 2). HTRA1 is widely expressed with the highest level detected in the placenta (Figure 2A), suggesting that it may have an important role in placental development and function [30-32]. The expression of $H T R A 2$, on the other hand, is ubiquitous and relatively uniform across many organs (Figure $2 \mathrm{~B}$ ), though one study reported that the foetal liver expresses the highest level of HTRA2 [26]. Like HTRA1, HTRA3 is also broadly expressed with high levels detected in the heart, smooth muscle, breast and the developing placenta (Figure 2C) [26,33].

In contrast, HTRA4 is not well expressed in humans, except in the placenta (Figure 2D) [24]. Moreover, placental HTRA4 expression is likely human/primate-specific, as no other species are reported to express HTRA4 abundantly in any tissues including the placenta. Liu et al. (2015) reported that Htra4 null mice have normal embryonic and placental development, with no obvious differences in placental structure or morphology compared to the wild-type [34]. Cross breeding of Htra4 knock-out mice produces similar pup numbers, further indicating that fertility is unaffected [34]. It is thus concluded that HtrA4 does not play a significant role in murine placentation or other HtrA family members have compensated for HtrA4 [34]. However, another explanation could be that Htra4 is not well expressed in mice, including the placenta, which is somewhat supported by this study, although future research needs to confirm this possibility. Regardless, in the human HTRA4 is highly expressed only in the placenta, setting HtrA4 apart from the other HtrAs. Studies to date suggest that HtrA4 exerts an important role in human placental development and pregnancy health, and in the pathogenesis of pregnancy complications [24,35-40], which will be discussed in detail later in this review. 

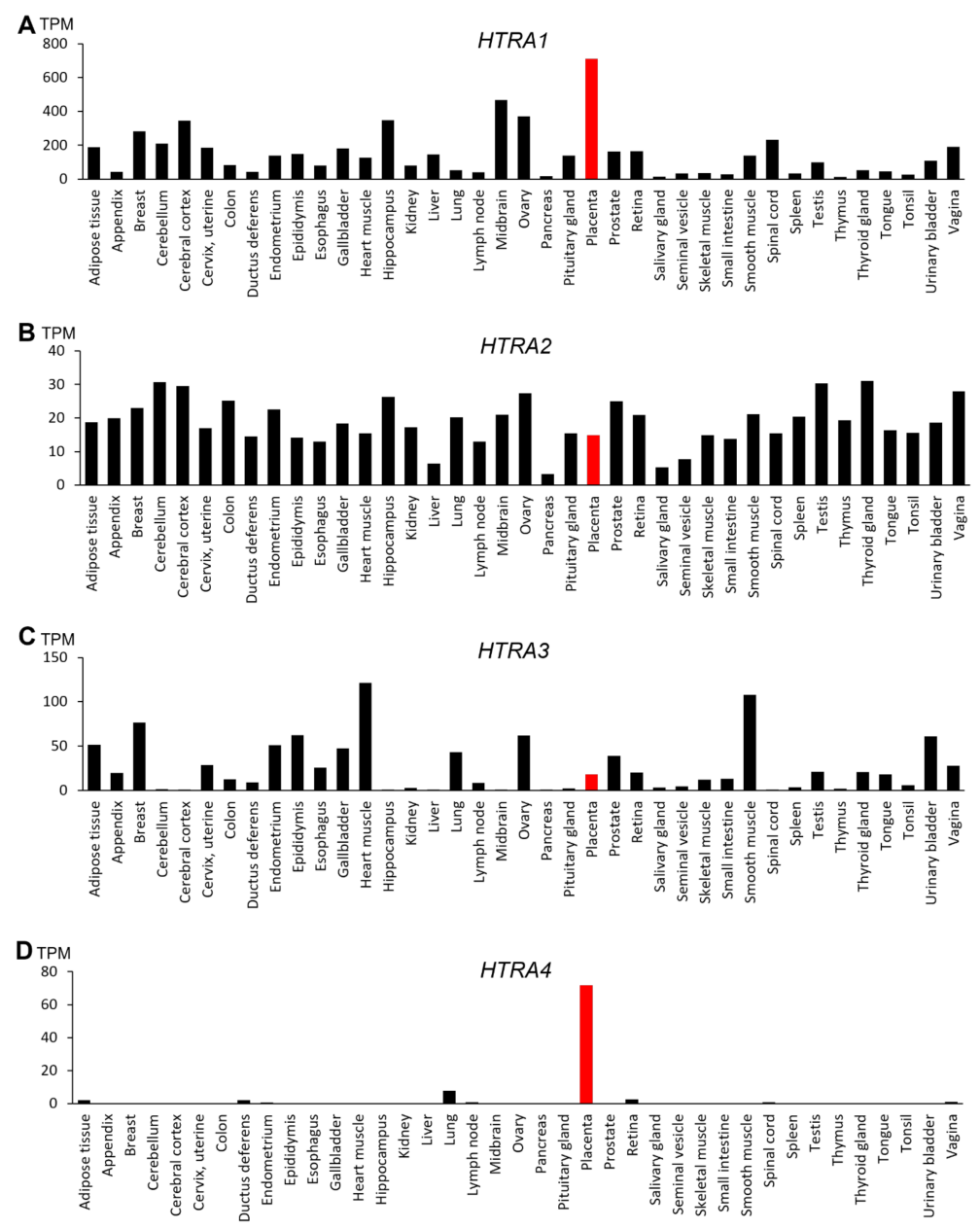

Figure 2. Gene expression profile of the four human HtrAs in 39 human tissues. Data obtained from National Centre for Biotechnology Information FANTOM5 dataset and expressed in transcripts per kilobase million (TPM). The placenta is highlighted in red. (A) HTRA1; (B) HTRA2; (C) HTRA3; (D) HTRA4.

\subsection{Key Molecular Characteristics}

Table 1 lists the key molecular features of the four human HtrAs. HTRA1 was initially identified as a gene downregulated in SV-40 transformed fibroblasts [41]. Located on chromosome 10q26.13, the gene consists of 9 exons and encodes a polypeptide of 480 amino acids with a mass of approximately $50 \mathrm{kDa}$ (Table 1). Although predominantly considered as a secretory protein, HtrA1 with a mass of $29 \mathrm{kDa}$ due to processing has been detected in the cytoplasm and within the nucleus of some tissues [42]. The HTRA2 gene is located on chromosome 2p13.1, containing 8 exons and encoding a protein of 458 amino acids and $49 \mathrm{kDa}$ in size (Table 1). HtrA3 was first identified as a pregnancy-related serine protease that is upregulated in the mouse uterus coinciding with placental development [27]. In the human, the HTRA3 gene is located on chromosome 4p16.1, comprising 10 exons which can be alternatively spliced to produce two protein isoforms-HtrA3L and HtrA3S [26]. The long variant (HTRA3L) lacks exon 7 and encodes for 453 amino acids ( $49 \mathrm{kDa})$, whereas the short variant (HTRA3S) lacks exons 8, 9 and 10 and encodes for 357 amino acids (38 kDa, missing the PDZ domain) [26]. HtrA4 was first identified as a serine protease associated with pregnancy [1]; the gene is located on chromosome 8p11.22, encompassing 9 exons which encode a protein of 476 amino acids with approximately $50 \mathrm{kDa}$ in size (Table 1). 
Table 1. Key features of human HtrAs.

\begin{tabular}{|c|c|c|c|c|}
\hline & HtrA1 & HtrA2 & HtrA3 & HtrA4 \\
\hline Approved name & HtrA serine peptidase 1 & $\begin{array}{l}\text { HtrA serine } \\
\text { peptidase } 2\end{array}$ & HtrA serine peptidase 3 & HtrA serine peptidase 4 \\
\hline Gene name & HTRA1 & HTRA2 & HTRA3 & HTRA4 \\
\hline Gene Synonyms & $\begin{array}{l}\text { ARMD7, CARASIL, } \\
\text { CADASIL2, HtrA, } \\
\text { IGFBP5-protease, L56, } \\
\text { ORF480, PRSS11 }\end{array}$ & $\begin{array}{l}\text { MGCA8, } \\
\text { OMI, } \\
\text { PARK13, } \\
\text { PRSS25 }\end{array}$ & $\begin{array}{l}\text { TASP, } \\
\text { PRSP }\end{array}$ & \\
\hline Entrez Gene ID & 5654 & 27,429 & 94,031 & 203,100 \\
\hline HGNC ID & 9476 & 14,348 & 30,406 & 26,909 \\
\hline Ensembl ID & ENSG00000166033 & ENSG00000115317 & ENSG00000170801 & ENSG00000169495 \\
\hline MEROPS ID & S01.277 & S01.278 & S01.284 & S01.285 \\
\hline Chromosoml location & $\begin{array}{c}10 \mathrm{q} 26.13 \\
(122,461,553-122,514,907) \\
\text { Plus strand }\end{array}$ & $\begin{array}{c}2 \mathrm{p} 13.1 \\
(74,529,405-74,533,556) \\
\text { Plus strand }\end{array}$ & $\begin{array}{c}4 \mathrm{p} 16.1 \\
(8,269,712-8,307,098) \\
\text { Plus strand }\end{array}$ & $\begin{array}{c}8 \mathrm{p} 11.22 \\
(38,974,228-38,988,663) \\
\text { Plus strand }\end{array}$ \\
\hline Gene size (bases) & 53,355 & 4152 & 37,387 & 14,436 \\
\hline RefSeq & $\begin{array}{l}\text { NM_002775 } \\
\text { NP_002766 }\end{array}$ & $\begin{array}{l}\text { NM_013247 } \\
\text { NP_037379 }\end{array}$ & $\begin{array}{l}\text { NM_053044 } \\
\text { NP_444272 }\end{array}$ & $\begin{array}{l}\text { NM_153692 } \\
\text { NP_710159 }\end{array}$ \\
\hline mRNA (bases) & 2091 & 1785 & 2539 & 2032 \\
\hline Number of exons & 9 & 8 & 10 & 9 \\
\hline Alternative splicing & $\begin{array}{l}2 \text { additional variants } \\
\text { predicted }\end{array}$ & $\begin{array}{l}9 \text { additional varaints } \\
\text { predicted with some } \\
\text { confirmed }\end{array}$ & $\begin{array}{l}1 \text { additional variant } \\
\text { confirmed }\end{array}$ & unknown \\
\hline UniProtKB/Swiss-Prot ID & Q92743 & O43464 & P83110 & P83105 \\
\hline Full lenght Protein (aa) & 480 & 458 & 453 & 476 \\
\hline Transient peptide & $\mathrm{N} / \mathrm{A}$ & 1-31 (31aa) & $\mathrm{N} / \mathrm{A}$ & $\mathrm{N} / \mathrm{A}$ \\
\hline Signal peptide & $1-22$ (22aa) & $\mathrm{N} / \mathrm{A}$ & 1-17 (17aа) & $1-31$ (31aa) \\
\hline Propeptide & $\mathrm{N} / \mathrm{A}$ & 32-133 (102) & $\mathrm{N} / \mathrm{A}$ & $\mathrm{N} / \mathrm{A}$ \\
\hline $\begin{array}{l}\text { Mature peptide } \\
\text { Mol_wt (dalton) }\end{array}$ & $\begin{array}{c}23-480 \text { (458aa) } \\
49,048\end{array}$ & $\begin{array}{c}134-458 \text { (325aa) } \\
34,981\end{array}$ & $\begin{array}{c}18-453 \text { (436aa) } \\
46,945\end{array}$ & $\begin{array}{c}32-476 \text { (445aa) } \\
47,685\end{array}$ \\
\hline Transmembrane & $\mathrm{N} / \mathrm{A}$ & $105-125$ (21aa) & N/A & $\mathrm{N} / \mathrm{A}$ \\
\hline IGF-binding domain & 33-100 (68aa) & $\mathrm{N} / \mathrm{A}$ & 21-77 (57aa) & 36-99 (64aa) \\
\hline Kazal-like domain & 98-157 (60aa) & N/A & 64-128 (65aa) & 88-154 (67aa) \\
\hline Serine protease domain & 204-364 (161aa) & 166-342 (177aa) & 175-340 (166aa) & 202-362 (161aa) \\
\hline PDZ domain & 365-467 (103aa) & $364-445$ (82aa) & 359-444 (86aa) & 383-474 (92aa) \\
\hline $\begin{array}{l}\text { Catalytic triad Histidine, } \\
\text { Aspartic acid and Serine }\end{array}$ & $\begin{array}{l}\mathrm{H} 220 \\
\mathrm{D} 250 \\
\mathrm{~S} 328 \\
\end{array}$ & $\begin{array}{l}\mathrm{H} 198 \\
\mathrm{D} 228 \\
\text { S306 }\end{array}$ & $\begin{array}{l}\mathrm{H} 191 \\
\mathrm{D} 227 \\
\mathrm{~S} 305 \\
\end{array}$ & $\begin{array}{l}\mathrm{H} 218 \\
\mathrm{D} 248 \\
\mathrm{~S} 326 \\
\end{array}$ \\
\hline Trimer stabilization sites & $\begin{array}{l}\text { Y169 } \\
\text { F171 } \\
\text { F278 }\end{array}$ & F149 & $\begin{array}{l}\text { Likely } \\
\text { F140 } \\
\text { F142 } \\
\text { F255 }\end{array}$ & $\begin{array}{l}\text { Likely } \\
\text { Y167 } \\
\text { F169 } \\
\text { F276 }\end{array}$ \\
\hline Protein binding sites & $\begin{array}{c}382 . .385 \\
387 \\
444 . .445 \\
448 \ldots 449\end{array}$ & $\begin{array}{c}361 . .364 \\
366 \\
423 . .424 \\
427 . .428\end{array}$ & $\begin{array}{c}356 \ldots 359 \\
361 \\
418 . .419 \\
422 . .423\end{array}$ & $\begin{array}{c}380 . .383 \\
385 \\
442-443 \\
446 . .447\end{array}$ \\
\hline IAP-binding motif & unknown & $134-137$ & unknown & unknown \\
\hline $\begin{array}{c}\text { Potential } \\
\text { phosphorylation sites }\end{array}$ & $\begin{array}{l}\text { S195, T237, } \\
\text { Y238, T365, } \\
\text { S367, S456 }\end{array}$ & $\begin{array}{c}\text { T51, T242, T54, T326, S96, } \\
\text { S330, T157, S400, } \\
\text { S212,T453 }\end{array}$ & $\begin{array}{l}\text { S214, } \\
\text { S334, } \\
\text { T363 }\end{array}$ & $\begin{array}{l}\text { S310, } \\
\text { Y314, } \\
\text { S424 }\end{array}$ \\
\hline
\end{tabular}

Given HtrA1, 3 and 4 are more evolutionarily evolved and share a similar domain architecture, the amino acid sequences of these three members are aligned (Figure 3 ) and compared (Table 2). Globally, they share around 50\% identity and $70 \%$ similarity in amino 
acids (Table 2). When individual domains are compared, the serine protease domain shows the highest conservation, with $>80 \%$ residues being similar (Table 2). In particular, the catalytic triad residues histidine, aspartic acid and serine, and the HtrA sequence motifs GNSGGPL and TNAHV, are completely conserved (Figure 3). However, significant divergences are apparent outside the protease domain (Table 2, Figure 3). For the signal peptide, HtrA1 shares $88 \%$ similarity with HtrA4, but only $50 \%$ with HtrA3, whereas HtrA3 and HtrA4 are not comparable (Table 2). For the IGFBP domain, HtrA3 is 58\% similar to HtrA1 or HtrA4, whereas the similarity is only 50\% between HtrA1 and HtrA4 (Table 2). Both the Kazal protease inhibitor domain and the PDZ domain are relatively more conserved, showing around $70 \%$ similarity among the members (Table 2).

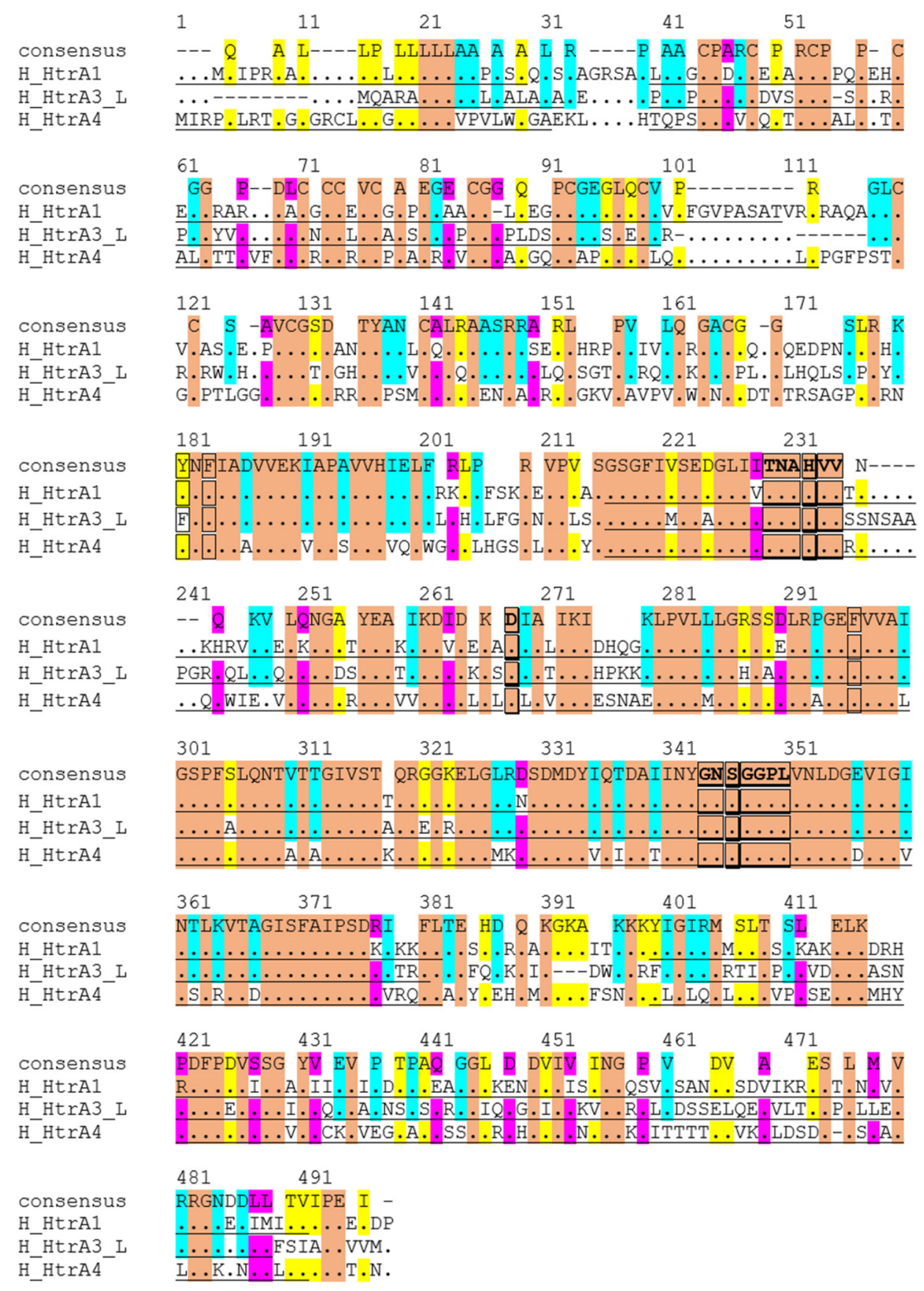

Figure 3. Alignment of amino acid sequences of human HtrA1, 3 and 4. Conserved amino acids are coloured: Orange, identical across all three HtrAs. Blue, similar between HtrA1 and HtrA3. Yellow, matching between HtrA1 and HtrA4. Pink, alike between HtrA3 and HtrA4. 
Table 2. Comparison of amino acid sequences of human HtrA1, 3 and 4 proteins.

\begin{tabular}{|c|c|c|c|c|c|c|c|}
\hline \multirow{2}{*}{\multicolumn{2}{|c|}{$\begin{array}{l}\text { Comparision between } \\
\text { HtrA Members }\end{array}$}} & \multicolumn{2}{|c|}{ HtrA1 vs. HtrA3 } & \multicolumn{2}{|c|}{ HtrA1 vs. HtrA4 } & \multicolumn{2}{|c|}{ HtrA3 vs. HtrA4 } \\
\hline & & Identity & Similarity & Identity & Similarity & Identity & Similarity \\
\hline & Overall & $58 \%$ & $73 \%$ & $54 \%$ & $70 \%$ & $51 \%$ & $68 \%$ \\
\hline \multirow{5}{*}{ 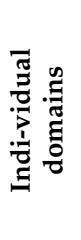 } & Signal peptide & $50 \%$ & $50 \%$ & $89 \%$ & $89 \%$ & - & - \\
\hline & IGFB & $52 \%$ & $58 \%$ & $45 \%$ & $50 \%$ & $50 \%$ & $58 \%$ \\
\hline & Kazal & $58 \%$ & $72 \%$ & $52 \%$ & $68 \%$ & $48 \%$ & $67 \%$ \\
\hline & Trypsin & $77 \%$ & $89 \%$ & $73 \%$ & $88 \%$ & $69 \%$ & $81 \%$ \\
\hline & PDZ & $41 \%$ & $71 \%$ & $41 \%$ & $68 \%$ & $41 \%$ & $70 \%$ \\
\hline
\end{tabular}

3. Function, Regulation, and Potential Substrates of Human HtrAs and Their Involvement of Various Diseases

\subsection{HtrA1}

HtrA1 has been implicated in a diverse range of pathological conditions, including cancer, age-related macular degeneration (AMD) and preeclampsia [17,23,43-47]. Each of the HtrA1 subdomains and their specific functions have been reported by different studies with contradictory findings. Truebestein et al. (2011) reported that substrate binding can directly mediate the remodelling of the active sites of HtrA1 to induce its proteolytic activity, while the PDZ domain is dispensable for substrate attachment or activation [48]. In contrast, Eigenbrot et al. (2012) showed that HtrA1 can exist in an active state in the absence of a substrate, whereby the substrate simply binds to the active HtrA1, and an unknown independent mechanism switches on its proteolytic activity to regulate equilibrium [29]. In general, the distinct sequence of the PDZ domain is thought to play a role in recognition and binding of specific substrates, as well as in the regulation of protease activities [49]. Studies of collagen C-propeptide cleavage showed that a binding of this substrate to the PDZ domain of HtrA1 is necessary to activate the protease activity [50]. In the same study, HtrA2 failed to significantly bind to collagen C-propeptide, or exhibit any increased protease activity, demonstrating the specific nature of the substrate recognition, binding and enzyme activity of different HtrAs [50]. Other domains of HtrA1 may also further refine the substrate specificity; one study shows that the serine protease domain and the preceding small linker region on the HtrA1 can mediate the binding and inhibition of transforming growth factor (TGF)- $\beta$ and bone morphogenetic protein (BMP) signalling, whereas the PDZ domain is not involved in the binding or protein-protein interaction [51].

To date, many physiological substrates of HtrA1 have been identified, implicating that HtrA1 has a wide range of biological functions in different tissues (Table 3). Consequently, aberrant HtrA1 activity has been linked to various human diseases, and many growth factors and matrix proteins have been identified as potential HtrA1 substrates (Table 3). For instance, HtrA1 is upregulated in various musculoskeletal diseases, coinciding with the increased fragmentation of several extracellular matrix (ECM) proteins that are known targets of HtrA1, which include fibronectin, type II collagen and decorin [47]. Increased HTRA1 expression is also implicated in AMD, which is closely associated with the increased degradation of various ECM proteins [52,53]. On the other hand, decreased level of HtrA1 is linked to dysregulation of TGF- $\beta$ signalling in cerebral small vessel disease, which can lead to early-onset stroke and dementia [54]. As a hereditary disease, cerebral autosomal recessive arteriopathy with sub-cortical infarcts and leukoencephalopathy (CARASIL) has been identified to contain mutations within the HTRA1 gene, which results in the loss of HtrA1 protein or reduced protease activities $[46,55]$. One of the proposed mechanisms of HtrA1 action is to process latent TGF- $\beta$ binding protein 1 (LTBP-1), an ECM protein that is required by TGF- $\beta$ signalling. This is supported by the observation that fibroblast cells isolated from CARASIL patients and from Htral knockout mice all show reduced LTBP-1 processing and attenuated TGF- $\beta$ activity [54]. However, an opposite effect of HtrA1 has also been reported, where it inhibits TGF- $\beta$ signalling during bone development 
via degrading TGF- $\beta$ type II and III receptors and preventing the activation of downstream TGF- $\beta$ signalling [56]. Indeed, embryonic fibroblasts isolated from mice with the Htra1 gene deletion show an increased expression of TGF- $\beta$-induced genes, and the bone mass in these mice is also increased due to the upregulation of TGF- $\beta$ activity [56]. These data suggest that HtrA1 may regulate specific proteins/pathways in a tissue-dependent manner. HTRA1 is also highly expressed in the brain and has been implicated in Alzheimer's disease. HtrA1 can directly degrade various fragments of amyloid precursor protein (APP), and inhibition of HtrA1 activity results in the accumulation of beta-amyloid in astrocytoma cell culture media; these data suggest a potential role of HtrA1 in protecting the brain against accumulation of amyloid deposits, which is a major neuropathological feature of Alzheimer's disease [43]. Furthermore, HtrA1 is demonstrated to degrade the aggregated and damaged tau, a protein that aggregates into intracellular neurofibrillary tangles in many neurological disorders such as Alzheimer's disease [57]. In neuronal PC12 cells, HtrA1 mRNA and activity are upregulated in response to tau, and in patient brain samples, the extent of tau aggregates inversely correlates to the level of HTRA1 expression; these results suggest an important role for HtrA1 in regulating protein quality control for neurological functions [57].

Table 3. Potential functions and substrates of human HtrAs in association with various diseases.

\begin{tabular}{|c|c|c|c|}
\hline HtrA Member & Functions and Substrates & Associated Diseases & References \\
\hline \multirow{6}{*}{ HtrA1 } & Degrading ECM proteins-fibronectin, type I collagen and decorin & Musculoskeletal diseases & [47] \\
\hline & Processing ECM proteins-EFEMP1 and TSP1 & $\begin{array}{l}\text { Age-related macular } \\
\text { degeneration }\end{array}$ & {$[52,53]$} \\
\hline & Processing ECM proteins-LTBP-1 & $\begin{array}{l}\text { Cerebral small vessel disease } \\
\text { CARASIL }\end{array}$ & {$[46,54]$} \\
\hline & Degrading APP and tau protein aggregates & Alzheimer's disease & {$[43,57]$} \\
\hline & $\begin{array}{l}\text { Degrading XIAP to activate caspase activity } \\
\text { Disruption of microtubules to inhibit cell migration }\end{array}$ & Cancer & {$[58,59]$} \\
\hline & $\begin{array}{l}\text { Processing ECM proteins or growth factors involved in trophoblast } \\
\text { migration and invasion }\end{array}$ & Preeclampsia & {$[31,37,60]$} \\
\hline \multirow{6}{*}{ HtrA2 } & Degrading unfolded or misfolded proteins & Parkinson's disease & {$[61,62]$} \\
\hline & $\begin{array}{l}\text { Breaking down APP in mitochondria to maintain normal cellular } \\
\text { function }\end{array}$ & Alzheimer's disease & [63] \\
\hline & Binding to and degrading IAPs to facilitate caspase activities & Cancer and chemoresistance & {$[64,65]$} \\
\hline & Degrading HAX-1 to promote cell death & $\begin{array}{l}\text { Mitochondria-related } \\
\text { dysfunction }\end{array}$ & [66] \\
\hline & Degrading Ped-Pea15 to promote cell death & $\begin{array}{l}\text { Environmental stressor-induced } \\
\text { cellular dysfunction }\end{array}$ & [67] \\
\hline & Degrading WTP1 to increase c-Myc and JunB to promote apoptosis & Cancer & {$[68,69]$} \\
\hline \multirow{5}{*}{ HtrA3 } & Cleaving ECM proteins-decorin and biglycan & Osteoarthritis and cancer & [70] \\
\hline & Cleaving cytoskeleton proteins-actin, $\beta$-tubulin and vimentin & $\begin{array}{l}\text { Destabilization of cytoskeleton } \\
\text { dynamics in cancer treatments }\end{array}$ & [71] \\
\hline & Acting as a chaperone by interacting with $\mathrm{TCP} 1 \alpha$ chaperonin & $\begin{array}{l}\text { Cancer and alteration of cancer } \\
\text { cells }\end{array}$ & [71] \\
\hline & Cleaving XIAP to promote drug-induced apoptosis & Cancer and chemoresistance & [72] \\
\hline & $\begin{array}{l}\text { Binding to BMP4, TGF- } \beta 1 \text {, TGF- } \beta 2 \text { and GDF5 to inhibit their } \\
\text { functions }\end{array}$ & $\begin{array}{l}\text { Placental development and } \\
\text { Preeclampsia }\end{array}$ & {$[22,70,73]$} \\
\hline \multirow{3}{*}{ HtrA4 } & Degrading fibronectin to impede trophoblast invasion & Preeclampsia & [74] \\
\hline & $\begin{array}{c}\begin{array}{c}\text { Cleaving endothelial junction protein VE-Cadherin to increase } \\
\text { permeability }\end{array}\end{array}$ & Preeclampsia & [40] \\
\hline & Cleaving VEGF-A receptor KDR to inhibit angiogenesis & $\begin{array}{l}\text { Endothelial dysfunction in } \\
\text { preeclampsia }\end{array}$ & [39] \\
\hline
\end{tabular}




\subsection{HtrA2}

While HtrA1, 3 and 4 are all secreted proteins, the precursor of HtrA2 resides in the mitochondrial intermembrane space and serves as protein quality control to maintain mitochondrial homeostasis under normal physiological conditions [75]. The loss of HtrA2 in mice leads to accumulations of unfolded proteins in the mitochondria, defective mitochondrial respiration, increased concentrations of reactive oxygen species (ROS) and neuronal cell death [61]. Mice without the HtrA2 proteolytic activity due to a mutation in the Htra2 gene, exhibit muscle wasting and neurodegeneration similar to symptoms of patients suffering from Parkinson's disease [62]. Several point mutations within the PDZ domain of the HTRA2 gene have been identified in patients with Parkinson's disease, and these mutations are demonstrated to result in HtrA2 inactivation and mitochondrial dysfunction in vitro [76]. However, a large-scale population-worldwide genetic association study has failed to find a strong link between HTRA2 variants and Parkinson's disease, thus the relevance of HtrA2 activity in Parkinson's disease remains to be further investigated [77].

Under stressful conditions, HtrA2 can switch from a pro-survival factor to a proapoptotic player to facilitate cell death [17]. Following stress stimuli, HtrA2 is released from the mitochondria into the cytosol, and subsequently binds to and degrades the inhibitor of apoptosis proteins (IAPs), thereby freeing up active caspases to induce apoptosis in the damaged or infected cells [64,65]. Environmental stresses such as tunicamycin or heat shock all increase HtrA2 expression in mammalian cells [78]. Cisplatin, a chemotherapeutic drug commonly used to treat various solid tumours, has also been shown to upregulate $\mathrm{HtrA} 2$ in a dose-dependent manner in both mouse and human renal cells; the knockdown of HTRA2 by siRNA or a HtrA2-specific inhibitor renders renal cells resistant to cisplatin-induced apoptosis [79]. Furthermore, HtrA2 also directly promotes cell death independent of the caspase pathway by degrading other antiapoptotic proteins, such as HS1-associated protein X (HAX)-1, proliferation and apoptosis adaptor protein 15 (PED-PEA15) and Wilms tumour protein 1 (WTP1) [66-68]. Therefore, HtrA2 functions as a crucial mediator of cell survival as well as cell death. However, unlike the other three human HtrA members, HtrA2 does not appear to be involved in placental development or pregnancy complications. Protein substrates and human diseases that are associated with HtrA2 are summarised in Table 3.

\subsection{HtrA3}

Like HtrA1, HtrA3 is secreted due to the presence of an N-terminal signal peptide [26]. However, HtrA3 has also been detected in the mitochondria, and a processed form lacking the $\mathrm{N}$-terminal domain has also been found in the cytoplasm, suggesting that the Nterminal region is necessary for HtrA3 transportation into the mitochondrion [80]. A detailed analysis of the HtrA3 subdomains has identified that neither the N-terminal nor the PDZ domain is required for enzyme activity or substrate binding [81]. However, the PDZ domain appears to be necessary for HtrA3 to form trimers; when the PDZ domain is removed both HtrA3S and HtrA3L are present as monomer, whereas HtrA3 with truncated $\mathrm{N}$-terminal forms a stable trimer [81]. This is unique to HtrA3, since both HtrA1 and HtrA2 remain trimeric following the removal of both the $\mathrm{N}$-terminal and the PDZ domains, which in turn suggests that the trimer formation of HtrA3 is less stable and requires the PDZ domain to interact with other regions to maintain stability [81]. Furthermore, in HtrA3S the C-terminal PDZ domain is replaced by a sequence of seven amino acids, yet its enzyme activity is not significantly impacted; it remains unknown whether this unique sequence has any specific roles [81].

Both HtrA3 isoforms are proteolytically active and can function either as proteases or chaperones [71,82]. Both isoforms can interact with cytoskeletal proteins such as actin, $\beta$-tubulin, vimentin and TCP1 chaperonin, which are important for actin and tubulin folding [71]. While both HtrA3 isoforms can cleave these proteins and function as chaperones in vitro, HtrA3S has more efficient proteolytic activities, whereas HtrA3L is the most efficient HtrA protein in facilitating tubulin polymerization [71]. Thus, the two HtrA3 
isoforms may have different roles and function either as proteases or chaperones depending on the tissue type [71].

Studies in mice have demonstrated that HtrA3 can bind to and inhibit various TGF- $\beta$ superfamily members, including BMP-4, TGF- $\beta 1$, TGF- $\beta 2$ and growth and differentiation factor (GDF)-5 [70]. Both HtrA1 and HtrA3 can degrade ECM proteins such as decorin and biglycan, which are mediators of TGF- $\beta$ signalling, suggesting that the two HtrAs may have complementary roles in the remodelling of ECM in specific tissues [70].

Furthermore, HtrA3 functions as a proapoptotic protein in mitochondria-mediated cell death [80]. Treatment of lung cancer cells with chemotherapeutic drugs etoposide and cisplatin causes autoproteolysis of $\mathrm{HtrA} 3$, leading to a product of $35 \mathrm{kDa}$ which lacks the N-terminal domain but contains the PDZ domain plus the full active protease domain, which is subsequently translocated from the mitochondria to the cytosol [80]. This translocation of HtrA3 coincides with an increase in cell death, which can be attenuated by either suppressing HTRA3 or overexpressing the anti-apoptotic factor B-cell lymphoma (BCL)-2 [80]. Moreover, forced HTRA3 expression significantly reduces lung cancer cell survival following treatment with etoposide and cisplatin, whereas an inactive mutant form of HtrA3 has no impact, suggesting that the protease activity of HtrA3 is essential in modulating drug-induced cytotoxicity in cancer cells [80]. However, the exact role of HtrA3 and its target substrates in programmed cell death are not well characterized. It is reported that both HtrA3 isoforms can bind to and cleave the X-linked inhibitor of apoptosis protein (XIAP) to significantly reduce its cellular levels in lung cancer cells when treated with etoposide, indicating a possible mechanism of $\mathrm{HtrA3}$ action in promoting cancer cell death following chemotherapy [72]. Both isoforms of HtrA3 without the N-terminal region are still able to cleave XIAP like their wildtype counterparts, suggesting that the N-terminal domain is not required for HtrA3 proteolytic activity [72]. The potential substrates of $\mathrm{HtrA} 3$ and their roles in various human diseases are presented in Table 3.

\subsection{HtrA4}

Examinations of various human tissues and cell lines have thus far detected abundant HTRA4 expression only in the human placenta (Figure 2) and BeWo cells (a choriocarcinoma trophoblast cell line) [24]. Though the full physiological role of HtrA4 in the placenta remains to be investigated, studies to date suggest that HtrA4 promotes trophoblast invasion during placental development $[74,83]$. In BeWo cells, when the endogenous HTRA4 expression is knocked down, cell invasiveness is greatly reduced [74]. In trophoblast-derived JAR cell line, the forced expression of the wild type HTRA4 but not an protease-inactive mutant increases invasion [74]. HtrA4 is shown to cleave the ECM protein fibronectin in vitro, indicating that it may facilitate cell invasion by disrupting the interaction between fibronectin and its integrin receptors that would otherwise impede trophoblast invasion $[74,84]$. Glial Cells Missing-1 (GCM1), a placenta-specific transcription factor, is shown to upregulate HtrA4 to promote invasion, which can be inhibited by the transcriptional factor GATA3 [85]. GATA3 alone has no effect on HtrA4 expression, but when co-expressed with GCM1, it suppresses GCM1-mediated luciferase activity in 293T cells transiently transfected with a HTRA4 reporter construct [85]. However, this is an artificial system since 293T cells are not trophoblasts and do not endogenously express HtrA4. The knockdown of GATA3 in BeWo cells elevates HtrA4 expression and increases cell invasive activity [85]. In trophoblast cell line JEG-3, which expresses very low levels of HTRA4, the knockdown of GATA3 leads to a marginal increase in HtrA4, suggesting other unknown factors are required to induce HtrA4 expression [24,85]. However, all above studies have used cell lines and it remains to be investigated if HtrA4 has a similar role in primary trophoblast cells and in vivo. HtrA4 was recently found to play an important role in trophoblast syncytialization, where its upregulation in primary trophoblast cells coincides with a surge in human chorionic gonadotrophin (HCG) release, which is a known indicator of syncytialization [86]. Furthermore, silencing of the HTRA4 gene in BeWo cells inhibits forskolin-induced syncytialization and HCG expression/secretion [86]. 
Since HtrA4 is secreted out of the placenta and detected in the blood circulation of pregnant women, it could impact endothelial cells. Indeed, recombinant human HtrA4 can cleave the main surface receptor for vascular endothelial growth factor (VEGF)-A which is also known as kinase insert domain receptor (KDR), causing an inhibition of VEGF-A action and endothelial dysfunction [39]. In addition, HtrA4 can cleave the main endothelial junctional protein vascular endothelial (VE)-cadherin, disrupting cell-cell connections and inducing intercellular gaps between endothelial cells [40]. Furthermore, HtrA4 may cleave other cell surface receptors such as TGF- $\beta$ type III receptor (TGF $\beta$ RIII), producing soluble receptors that can inhibit TGF- $\beta$ function [87]. The involvement of HtrA4 in pregnancy complications such as preeclampsia will be further discussed in a later part of this review.

Studies have explored the potential role of HtrA4 in cancer cell lines, reporting that HtrA4 promotes cell death by degrading XIAP and pro-caspase 7, which was shown previously for HtrA1 and 3 in cancer cells $[88,89]$. Several other proteins have also been identified as potential substrates of HtrA4, notably cytoskeleton proteins actin and tubulin, TCP1 chaperonin and S100A6 calcium-binding protein, through which HtrA4 may exert an effect on cytoskeleton homeostasis [90]. These studies present potential insights into the possible mechanisms of HtrA4 action [89,90]. However, so far, HtrA4 expression has not been shown in any primary cancer cells or in vivo tumours. The potential substrates of HtrA4 and its role in human diseases are summarised in Table 3.

\section{HtrAs and Various Cancers}

\subsection{HtrA1}

HTRA1 is widely expressed in many cancers. Table 4 summarises RNA-seq data sets retrieved from 17 different cancer types, and HTRA1 is expressed in all cancers examined with the highest levels detected in glioma, breast and pancreatic cancer. HTRA1 is broadly downregulated in cancer (Table 5), consist with a previous review [91]. In general, a reduced expression of HtrA1, and in some instances a complete absence of HtrA1, is associated with poor prognosis of many cancers such as ovarian, metastatic melanoma, breast carcinoma, prostate and lung tumours (Table 5) [92-97].

HtrA1 is suggested to function as a tumour suppressor to promote cell death; studies with metastatic melanoma cells show that an overexpression of HtrA1 inhibits cell proliferation in vitro and prevents tumour outgrowth in vivo [92,93]. However, the mechanisms of HtrA1 action in promoting cell death are not well understood. One study suggests that HtrA1 can directly degrade XIAP, leading to the activation of caspase cascade for apoptosis [58]. Another study reports that an overexpression of HtrA1 in ovarian cancer cells inhibits epidermal growth factor receptor (EGFR) activation, leading to lower levels of AKT/MAPK phosphorylation and a significant rise in cell death [98]. It is further suggested that the serine protease activity of HtrA1 is necessary for the attenuation of EGFR-induced cell survival, because an HtrA1 mutant form lacking the protease activity fails to induce cell death [98]. Moreover, in vitro studies show that HtrA1 disrupts the microtubule networks by directly targeting tubulins for degradation; in ovarian cancer cells, HTRA1 knockdown enhances cell migration, whereas HTRA1 overexpression attenuates it, suggesting that HtrA1 may regulate cancer metastasis [59]. Anti-cancer drugs, such as cisplatin and paclitaxel, are shown to upregulate HtrA1 which undergoes autocatalytic activation to initiate programmed cell death [99]. Since cancer patients who express low levels of HtrA1 have poorer responses to a few chemotherapy drugs, it is suggested that HtrA1 may serve as a potentially useful biomarker in selecting chemotherapy treatments [99]. The expression patterns of HtrA1 in different cancers are summarised in Table 5.

\section{2. $H \operatorname{tr} A 2$}

HTRA2 is also widely detected in many cancers (Table 4); however, its regulation is variable depending on the type of tumour (Table 5) [91]. As mentioned previously, HtrA2 is released from the mitochondria into the cytosol upon apoptotic stimulus to regulate cell death. It is reported that both HtrA2 mRNA and protein are significantly elevated 
in epithelial ovarian carcinoma in correlation to the stage of cancer progression [100]. Furthermore, ovarian cancer cells with higher levels of HtrA2 are more sensitive to cisplatin, and the knockdown of HTRA2 in these cells drastically increases cisplatin resistance and increases cell invasiveness [101]. A similar pattern of HtrA2 expression has been reported for prostate cancer [102] and stomach tumour [103]. However, HtrA2 is reported to be downregulated in other cancers. For instance, microarray analysis has revealed that $\mathrm{HtrA} 2$ is reduced in primary prostate cancer, and the reduction in metastatic cancer is even greater when compared to a normal prostate [104]. HtrA2 is also reported to be reduced in malignant breast tumours with increasing tumour stage and severity [105]. The variable HtrA2 regulation in cancer is summarised in Table 5. Further investigations are required to clarify the involvement of $\mathrm{HtrA} 2$ in different cancers and its potential use as a therapeutic target.

Table 4. Expression of human HtrAs in cancer patients. RNA-seq data extracted from the Cancer Genome Atlas (TCGA) dataset, levels in fragments per kilobase of transcript per million mapped reads (FPKM).

\begin{tabular}{ccccc}
\hline Cancer Type & \multicolumn{4}{c}{ mRNA Levels in FPKM } \\
\cline { 2 - 4 } & HTRA1 & HTRA2 & HTRA3 & HTRA4 \\
\hline Glioma $(n=153)$ & 192.4 & 12.2 & 2.3 & 0.1 \\
\hline Thyroid cancer $(n=501)$ & 42.8 & 7.1 & 3.2 & 0.2 \\
\hline Lung cancer $(n=994)$ & 36.2 & 8 & 15.9 & 0.5 \\
\hline Colorectal cancer $(n=597)$ & 23.4 & 7.9 & 11.9 & 0.1 \\
\hline Head and neck cancer $(n=499)$ & 58.3 & 7.5 & 12.6 & 0.1 \\
\hline Stomach cancer $(n=354)$ & 34.2 & 5 & 14.2 & 0.2 \\
\hline Liver cancer $(n=365)$ & 57.5 & 5.6 & 0.8 & 0 \\
\hline Pancreatic cancer $(n=176)$ & 93.5 & 7.2 & 56.9 & 0.4 \\
\hline Renal cancer $(n=877)$ & 79.6 & 8.4 & 1.2 & 0.4 \\
\hline Urothelial cancer $(n=406)$ & 36.5 & 8.3 & 9.1 & 0.1 \\
\hline Prostate cancer $(n=494)$ & 23.4 & 7.2 & 5.7 & 0.1 \\
\hline Testis cancer $(n=134)$ & 10.4 & 7.8 & 3.3 & 0.6 \\
\hline Breast cancer $(n=1075)$ & 102.4 & 7.6 & 24.5 & 0.2 \\
\hline Cervical cancer $(n=291)$ & 32.2 & 7.7 & 5.3 & 0.2 \\
\hline Endometrial cancer $(n=541)$ & 46.4 & 7.7 & 6.4 & 0.2 \\
\hline Ovarian cancer $(n=373)$ & 47.8 & 9.1 & 4.3 & 0.1 \\
\hline Melanoma $(n=102)$ & 26.8 & 9.5 & 3 & 0.1 \\
\hline & & & \\
\hline
\end{tabular}

\section{3. $\operatorname{Htr} A 3$}

HTRA3 is likewise detected in most tumours except liver cancer (Table 4). Pancreatic cancer has the highest HTRA3 expression compared to other tumours (Table 4). HTRA3 dysregulation has also been implicated in many malignancies (Table 5), with HtrA3 being proposed as a tumour suppressor [81]. Like HtrA2, HTRA3 expression is variable in cancer depending on the tumour type. HTRA3 is reported to be downregulated in many cancer cell lines and primary tumours, including ovarian, endometrial, breast and lung cancers $[20,106-113]$. Correspondingly, HtrA3 protein is also significantly lower in ovarian cancer tissues, consistent with the theory that HtrA3 may play an important role in promoting programmed cell death in ovarian cancer [107]. Likewise, HtrA3 protein is lower in breast cancer, especially if lymphatic metastasis has occurred [111]. In lung cancer, HtrA3 is shown to promote cell death following treatment with chemotherapeutic drugs, and HTRA3 knockdown renders these cells resistant to anti-tumour drugs [80]. HtrA3 can 
also inhibit lung cancer cell invasion, and the levels of HtrA3 negatively correlate to the increased risk of postoperative recurrence of non-small-cell lung cancer [113]. In contrast, HtrA3 is reported to be upregulated in oesophageal adenocarcinoma [114], pancreatic adenocarcinoma [115] and seminoma of the testis [116]. Hematologic cancers have variable levels of HtrA3 depending on the specific molecular alteration [91]. For instance, HtrA3 is downregulated in B-cell and T-cell acute lymphoblastic leukemia and acute myeloid leukemia, yet HtrA3 is significantly increased in acute lymphoblastic leukemia where chromosome translocation has occurred at 11q23/MLL or TCF3/PBX1 [117]. Therefore, alterations of $\mathrm{HtrA} 3$ in cancer are tissue-specific, and the underlying molecular changes associated with HtrA3 need to be investigated in different tumours. The expression pattern of HtrA3 in various cancers is summarised in Table 5.

Table 5. Regulation of human HtrAs reported in primary studies of cancer.

\begin{tabular}{|c|c|c|c|}
\hline HtrA Member & Type of Cancer & $\begin{array}{l}\text { Changes in } \\
\text { Expression }\end{array}$ & References \\
\hline \multirow{7}{*}{ HtrA1 } & Ovarian cancer & $\downarrow$ & {$[19,92,99]$} \\
\hline & Metastatic melanomas & $\downarrow$ & [93] \\
\hline & Breast carcinoma & $\downarrow$ & {$[94,118]$} \\
\hline & Metastatic prostate cancer & $\downarrow$ & [95] \\
\hline & Lung cancer & $\downarrow$ & {$[96]$} \\
\hline & Endometrial cancer & $\downarrow$ & {$[20,97]$} \\
\hline & Mesotheliomas & $\downarrow$ & [119] \\
\hline \multirow{4}{*}{ HtrA2 } & Ovarian cancer & $\uparrow$ & [100] \\
\hline & Prostate cancer & Inconsistent & {$[102,104]$} \\
\hline & Stomach cancer & $\uparrow$ & {$[103,105]$} \\
\hline & Breast cancer & $\downarrow$ & [105] \\
\hline \multirow{8}{*}{ HtrA3 } & Ovarian cancer & $\downarrow$ & {$[19,106,107]$} \\
\hline & Endometrial cancer & $\downarrow$ & {$[20,109]$} \\
\hline & Breast cancer & $\downarrow$ & [111] \\
\hline & Lung cancer & $\downarrow$ & {$[80,113]$} \\
\hline & Oesophageal adenocarcinoma & $\uparrow$ & {$[114]$} \\
\hline & Pancreatic adenocarcinoma & $\uparrow$ & [115] \\
\hline & Testicular seminoma & $\uparrow$ & [116] \\
\hline & Haematologic cancer & Variable & [117] \\
\hline HtrA4 & Not reported & Not reported & \\
\hline
\end{tabular}

\section{4. $H \operatorname{tr} A 4$}

To date, no studies have reported HTRA4 expression in primary tumour samples, although a previous review has suggested that HtrA4 may be dysregulated in some cancers such as glioblastoma, breast carcinoma, and primary prostate carcinoma [91]. However, RNA-seq data available for 17 different cancers (total $n=7932$ ) show very little HTRA4 expression in any of them (Table 4), including the three cancer types mentioned above, consistent with HTRA4 expression being limited to the placenta (Figure 2) [24].

\section{HtrAs in Placental Development and Pregnancy Complications}

\subsection{HtrA1}

HTRA1 is well expressed in the human placenta (Figure 2A), and its levels are highest in the third trimester [31]. Serum levels of HtrA1 also increase progressively with 
increasing gestation, and the highest levels are likewise detected in the third trimester [23]. Both HtrA1 mRNA and protein are detected in endometrial glands and decidual cells during the endometrial preparation of embryo implantation, and their levels are increased during early pregnancy [32]. In the first trimester placenta, HtrA1 is immuno-localised to villous trophoblasts, syncytiotrophoblasts and cytotrophoblasts [21]. In the third trimester, immunostaining of HtrA1 is more intensified and mainly localised to the syncytiotrophoblasts and the maternal decidual cells, and studies suggest that HtrA1 may target different intracellular growth factors or ECM proteins to modulate placental development and function [31].

Htra1 knockout mice are viable and fertile; however, both the placenta and the pups are reduced in size, and the placenta shows impaired arterial remodelling [120]. HtrA1 is speculated to regulate trophoblast-decidual interactions and trophoblast invasion, which are crucial for normal placentation [83,121]. HTR-8/SVneo cells, a trophoblast-like cell line, exhibit reduced migration and invasion in the presence of HtrA1, suggesting that aberrant levels of HtrA1 may disrupt placental development by attenuating trophoblast cell migration and invasion [60].

Several studies have reported an association between HtrA1 dysregulation and preeclampsia, especially the early-onset subtype which occurs before 34 weeks of gestation and usually presents with more severe forms of the disease $[23,37,60,122]$. Placental HTRA1 expression is upregulated in the third trimester when early-onset preeclampsia manifests [37,60], and HtrA1 serum levels are likewise elevated [23], making it a potential diagnostic marker. However, serum HtrA1 is not altered in the first or second trimester prior to the presentation of early-onset preeclampsia [123], indicating that HtrA1 is not useful for predicting the disease.

\subsection{HtrA3}

HtrA3 was first identified as a pregnancy-associated factor that is distinctly expressed during embryo implantation and placental development [27,33]. In human pregnancies, placental HtrA3 expression is strongest during the first trimester with high levels detected in the syncytiotrophoblasts [22,33]. HtrA3 levels in the maternal circulation reflects placental production, with the highest levels also detected in the first trimester. Placental and serum levels of HtrA3 drastically reduce from the second trimester onwards, which is likely induced by changes in oxygen tension from a low to a high concentration environment [22]. Animal studies have revealed that abundant $\mathrm{HtrA} 3$ expression during early pregnancy may be important for placental development and embryo growth [124,125], a finding that is supported by in vitro studies demonstrating that $\mathrm{HtrA3}$ negatively regulates trophoblast invasion [126,127].

Htra3 knockout mice are phenotypically normal and fertile; however, the placenta displays disorganization in labyrinthine foetal capillaries and foetus shows growth restriction, suggesting an important role for $\mathrm{Htr} \mathrm{A} 3$ in regulating placental development and function [128]. Furthermore, mice born to HtrA3-deficient mothers, irrespective of their own genotypes, are significantly heavier with more white fat in their adulthood, indicating that maternal HtrA3 may have a long-term impact on the offspring well beyond in utero growth [128].

The dysregulation of HtrA3 in the first trimester is linked to pregnancy complications. Women who are destined to develop preeclampsia have significantly higher levels of serum HtrA3 at 13-14 weeks of gestation, well before clinical symptoms manifest [22,73]. Furthermore, serum levels of HtrA3 at 11-13 weeks as well as at 15 weeks of gestation are significantly lower in pregnancies that proceed with subsequent intrauterine growth restriction (IUGR) $[128,129]$. These studies collectively suggest that an optimal concentration of HtrA3 during early pregnancy is necessary for the development of a functional placenta, and that HtrA3 may be a potentially useful biomarker for the early diagnosis/prediction of preeclampsia and IUGR [130]. 


\subsection{HtrA4}

As stated earlier, HTRA4 is uniquely expressed in the human placenta and secreted into the maternal circulation. In normal pregnancies, HtrA4 serum levels increase considerably from 11-13 weeks until 24-25 weeks of gestation, and then remain stable throughout the remainder of the pregnancy [24]. Several studies have linked abnormal placental expression of HtrA4 to early-onset preeclampsia [24,35,37]. Gene expression analyses consistently show a significant upregulation of HTRA4 in severe preeclampsia compared to their gestational-matched controls [24,35,37,131-134]. Furthermore, HtrA4 levels in the maternal circulation are significantly elevated in the third trimester at the diagnosis of early-onset preeclampsia $[24,35]$, and the circulating HtrA4 levels positively correlate to the severity of preeclampsia [35].

Contrary to the norm, studies by Wang et al. (2012) report that the intensity of HtrA4 immunostaining was lower in preeclamptic placentas [74]. However, the study examined only two placentas from late-onset preeclampsia. These seemingly conflicting reports suggest that HtrA4 expression may differ between different subtypes of preeclampsia, and that significant elevation of HtrA4 is likely a distinct characteristic of early-onset preeclampsia. This is supported by Inagaki et al. (2012) who compared the mRNA expressions of all four HtrAs in placentas from severe preeclamptic (average gestational age 33.9 weeks) vs normotensive (average gestational age 36.6 weeks) pregnancies, only HTRA1 and HTRA4 were significantly upregulated in the preeclamptic group [35]. Immunohistochemistry localised HtrA4 primarily to the cytotrophoblasts and syncytiotrophoblasts in placental villi, and HtrA4 staining was more intense in the preeclamptic placentas [35]. The same study also reported that HtrA4 serum levels were significantly higher in preeclamptic pregnancies, and that the levels were inversely correlated to placental and foetal weight, suggesting that elevated HtrA4 may adversely impact placental development and foetal growth [35]. HTRA4 mRNA is subsequently confirmed to be significantly upregulated in the placenta of early-onset preeclampsia, and HtrA4 serum levels are likewise highly elevated at the time of disease presentation [24]. Taken together, these findings suggest that excessive placental production HtrA4 may be more associated with early-onset preeclampsia [24].

Since placental HtrA4 is secreted into the maternal blood, elevated circulating HtrA4 may adversely impact the maternal vasculature and contribute to systemic endothelial dysfunction, which is often observed in early-onset preeclampsia. Studies indeed suggest that HtrA4 can disrupt endothelial cell function [24,36,38-40,135]. Recombinant HtrA4 can cleave endothelial junctional protein VE-Cadherin, disrupting F-actin organisation and increasing the number of intercellular gaps [24,40], which may explain why HtrA4 dose-dependently reduces the monolayer integrity of human umbilical vein endothelial cells (HUVECs) and increases cell permeability [24]. Primary HUVECs isolated from preeclamptic women also show such characteristics, including reductions in VE-Cadherin levels and increases in cell permeability [136].

Furthermore, in HUVECs as an endothelial cell model, HtrA4 considerably alters the expression of a range of genes involved in inflammation, angiogenesis, vaso-activity, platelet activation, cell adhesion and coagulation [36]. In particular, HtrA4 upregulates the expression of pro-inflammatory factors IL6, PTGS2 and IL1B to a level equivalent to that observed in early-onset preeclampsia [36]. The IL6 protein is also significantly elevated in HUVEC media, consistent with its mRNA changes. Moreover, HtrA4 upregulates the expression of THBD mRNA [36], consistent with THBD protein being elevated in preeclamptic serum $[137,138]$. On the other hand, THBS1, which is closely involved in endothelial adhesion, motility and proliferation, is significantly downregulated by HtrA4, consistent with THBS1 being lower in women with severe preeclampsia [139]. All the above evidence suggests that high levels of circulating HtrA4 may alter endothelial cell biology in early-onset preeclampsia [36].

High levels of HtrA4 also inhibit endothelial cell proliferation [38]. At the molecular level, HtrA4 downregulates many genes that are involved in cell cycle regulation, including cell proliferation marker Ki67 [38]. HtrA4 may also impact the circulating endothelial pre- 
cursor cells termed endothelial progenitor cells (EPCs), which can be recruited to the site of endothelial injury for repair [140]. HtrA4 inhibits the proliferation of primary EPCs isolated from pregnant women without affecting cell viability. HtrA4 likewise downregulates cell cycle genes in EPCs, and profoundly reduces Ki67 levels [38]. Furthermore, EPCs treated with HtrA4 are unable to form tube-like structures on Matrigel, suggesting that high levels of HtrA4 can prevent EPCs from differentiating into mature endothelial cells, which may hinder the repair and the restoration of damaged endothelial cells [38].

Moreover, HtrA4 promotes cellular senescence in both HUVECs and primary EPCs [135]. HtrA4 significantly upregulates senescence genes while downregulating those responsible for cell cycling and DNA repair [135], suggesting that high levels of circulating HtrA4 may promote endothelial cell senescence and aging, which are major risk factors of cardiovascular disease. The adverse impacts of HtrA4 on endothelial cells are summarised in Table 6.

Table 6. Potential impact of human HtrA4 protein on endothelial cells in preeclampsia.

\begin{tabular}{ccc}
\hline Impact & $\begin{array}{c}\text { Molecular Mechanisms of HtrA4 } \\
\text { Action }\end{array}$ & References \\
\hline $\begin{array}{c}\text { Stimulation of endothelial cell } \\
\text { proinflammation }\end{array}$ & Upregulating proinflammatory factors & [36] \\
\hline $\begin{array}{c}\text { Inhibition of endothelial cell } \\
\text { proliferation }\end{array}$ & $\begin{array}{c}\text { Downregulating cell cycle genes, } \\
\text { including cell proliferation marker Ki67 }\end{array}$ & [38] \\
\hline $\begin{array}{c}\text { Inhibition of proliferation and } \\
\text { differentiation of endothelial } \\
\text { progenitor cells }\end{array}$ & $\begin{array}{c}\text { Downregulating cell cycle genes and } \\
\text { inhibiting tube formation }\end{array}$ & [135] \\
\hline $\begin{array}{c}\text { Promotion of cellular senescence } \\
\text { downregulating genes involved in DNA } \\
\text { repair }\end{array}$ & $\begin{array}{c}\text { Upregulating senescence genes and } \\
\text { Inhibition of angiogenesis }\end{array}$ & $\begin{array}{c}\text { Cleaving VEGF-A receptor KDR to } \\
\text { inhibit VEGF-A action }\end{array}$ \\
\hline Enhancement of cellular permeability & $\begin{array}{c}\text { Cleaving VE-Cadherin to disrupt cell } \\
\text { contact integrity }\end{array}$ & {$[24,40]$} \\
\hline
\end{tabular}

The potential protein targets of HtrA4 in endothelial cells are listed in Table 3. HtrA4 can cleave the main VEGF-A receptor KDR to inhibit VEGF-A-dependent angiogenesis and endothelial cell function [39]. For instance, VEGF-A-induced tube formation and Akt activity are significantly reduced in HtrA4-treated HUVECs in concert with KDR reductions, demonstrating that HtrA4 can inhibit VEGF-A action [39]. This is further demonstrated in explants of mouse aortic rings [39]. Upon treatment with VEGF-A, abundant micro-vessels form around the outer layer of these rings; however, HtrA4 dosedependently inhibits such VEGF-dependent vessel growth [39]. Since VEGF-A is a crucial mediator of various endothelial functions including proliferation, permeability, migration and survival, HtrA4 cleavage of KDR may have a profound impact on endothelial cells (Figure 4). Collectively, these data point to HtrA4 as a potential contributor of endothelial dysfunction in early-onset preeclampsia. 


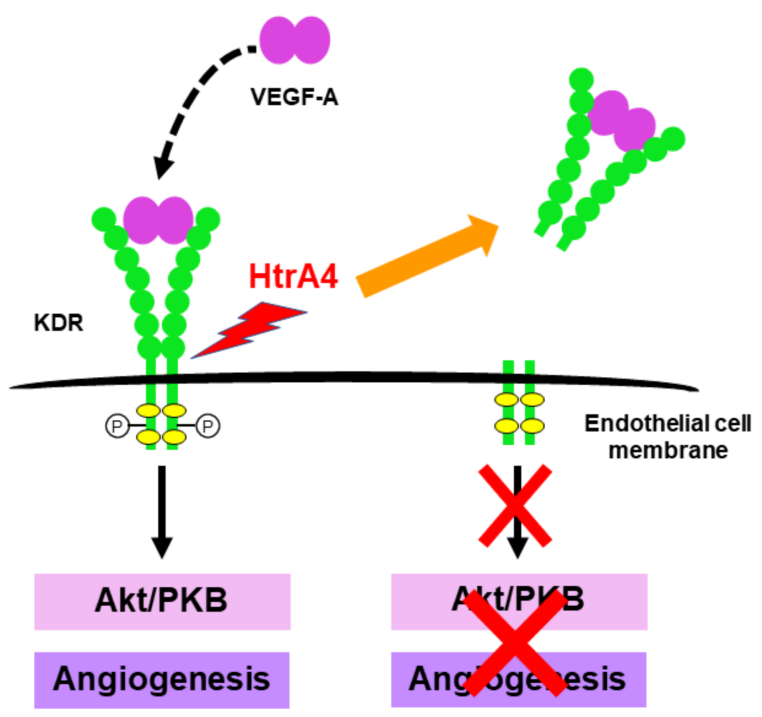

Figure 4. Predicted model of HtrA4 action in inhibiting VEGF-A function. VEGF-A binds to its cell surface receptor KDR to induce downstream Akt activity and endothelial cell function. HtrA4 cleavage of KDR prevents VEGF-A from eliciting downstream cell signalling and angiogenesis.

\section{Conclusions}

The HtrA family of proteases are essential cellular regulators that are involved in many processes, including cell death, modulation of ECM proteins, mitochondrial homeostasis and trophoblast invasion. Since they all have multiple functions, their aberrant expression may have a significant impact on human health and on the development of various diseases, such as cancer, Alzheimer's disease, AMD and preeclampsia. Of the four family members, HtrA4 is most unique because of its restricted expression to the human placenta. On one hand, HtrA4 likely plays an important role in placental development. On the other hand, excessive production of HtrA4 may adversely impact the placenta and maternal endothelium, contributing to pregnancy complications such as preeclampsia. More research into the tissue-specific regulation and functions of HtrAs will provide a better understanding of their distinctive physiological and pathological roles.

Author Contributions: Conceptualization, Y.W. and G.N.; software, Y.W.; formal analysis, Y.W.; investigation, Y.W.; resources, Y.W.; data curation, Y.W.; writing-original draft preparation, Y.W.; writing-review and editing, Y.W. and G.N; visualization, Y.W.; supervision, G.N.; project administration, G.N.; funding acquisition, Y.W. and G.N. All authors have read and agreed to the published version of the manuscript.

Funding: This review is supported by National Health and Medical Research Council of Australia [grants \#1139568 and \#1189145 to GN, and Dora Lush (biomedical) research scholarship to Y.W.], and the Victorian State Government Operational Infrastructure Scheme.

Conflicts of Interest: The authors declare no conflict of interests.

\section{References}

1. Clausen, T.; Southan, C.; Ehrmann, M. The HtrA family of proteases: Implications for protein composition and cell fate. Mol. Cell 2002, 10, 443-455. [CrossRef]

2. Clausen, T.; Kaiser, M.; Huber, R.; Ehrmann, M. HTRA proteases: Regulated proteolysis in protein quality control. Nat. Rev. Mol. Cell Biol. 2011, 12, 152-162. [CrossRef] [PubMed]

3. Lee, H.J.; Zheng, J.J. PDZ domains and their binding partners: Structure, specificity, and modification. Cell Commun. Signal. 2010, 8, 8. [CrossRef]

4. Lipinska, B.; Zylicz, M.; Georgopoulos, C. The HtrA (DegP) protein, essential for Escherichia coli survival at high temperatures, is an endopeptidase. J. Bacteriol. 1990, 172, 1791-1797. [CrossRef]

5. Chang, Z. The function of the DegP (HtrA) protein: Protease versus chaperone. IUBMB Life 2016, 68, 904-907. [CrossRef] [PubMed] 
6. Wilken, C.; Kitzing, K.; Kurzbauer, R.; Ehrmann, M.; Clausen, T. Crystal structure of the DegS stress sensor: How a PDZ domain recognizes misfolded protein and activates a protease. Cell 2004, 117, 483-494. [CrossRef]

7. Krojer, T.; Sawa, J.; Schafer, E.; Saibil, H.R.; Ehrmann, M.; Clausen, T. Structural basis for the regulated protease and chaperone function of DegP. Nature 2008, 453, 885-890. [CrossRef] [PubMed]

8. Spiess, C.; Beil, A.; Ehrmann, M. A temperature-dependent switch from chaperone to protease in a widely conserved heat shock protein. Cell 1999, 97, 339-347. [CrossRef]

9. Israeli, M.A.; Elia, U.; Rotem, S.; Cohen, H.; Tidhar, A.; Bercovich-Kinori, A.; Cohen, O.; Chitlaru, T. Distinct Contribution of the HtrA Protease and PDZ Domains to Its Function in Stress Resilience and Virulence of Bacillus anthracis. Front. Microbiol. 2019, 10, 255. [CrossRef] [PubMed]

10. Ingmer, H.; Brondsted, L. Proteases in bacterial pathogenesis. Res. Microbiol. 2009, 160, 704-710. [CrossRef]

11. Sgouras, D.; Tegtmeyer, N.; Wessler, S. Activity and Functional Importance of Helicobacter pylori Virulence Factors. Adv. Exp. Med. Biol. 2019, 1149, 35-56.

12. Hansen, G.; Hilgenfeld, R. Architecture and regulation of HtrA-family proteins involved in protein quality control and stress response. Cell. Mol. Life Sci. CMLS 2013, 70, 761-775. [CrossRef] [PubMed]

13. Zaide, G.; Elia, U.; Cohen-Gihon, I.; Israeli, M.A.; Rotem, S.; Israeli, O.; Ehrlich, S.; Cohen, H.; Lazar, S.; Beth-Din, A.; et al. Comparative Analysis of the Global Transcriptomic Response to Oxidative Stress of Bacillus anthracis htrA-Disrupted and Parental Wild Type Strains. Microorganisms 2020, 8, 1896. [CrossRef] [PubMed]

14. Figaj, D.; Ambroziak, P.; Przepiora, T.; Skorko-Glonek, J. The Role of Proteases in the Virulence of Plant Pathogenic Bacteria. Int. J. Mol. Sci. 2019, 20, 672. [CrossRef]

15. Backert, S.; Bernegger, S.; Skórko-Glonek, J.; Wessler, S. Extracellular HtrA serine proteases: An emerging new strategy in bacterial pathogenesis. Cell. Microbiol. 2018, 20, e12845. [CrossRef] [PubMed]

16. Zurawa-Janicka, D.; Wenta, T.; Jarzab, M.; Skorko-Glonek, J.; Glaza, P.; Gieldon, A.; Ciarkowski, J.; Lipinska, B. Structural insights into the activation mechanisms of human HtrA serine proteases. Arch. Biochem. Biophys. 2017, 621, 6-23. [CrossRef]

17. Zurawa-Janicka, D.; Skorko-Glonek, J.; Lipinska, B. HtrA proteins as targets in therapy of cancer and other diseases. Expert Opin. Ther. Targets 2010, 14, 665-679. [CrossRef] [PubMed]

18. Welsh, J.B.; Zarrinkar, P.P.; Sapinoso, L.M.; Kern, S.G.; Behling, C.A.; Monk, B.J.; Lockhart, D.J.; Burger, R.A.; Hampton, G.M. Analysis of gene expression profiles in normal and neoplastic ovarian tissue samples identifies candidate molecular markers of epithelial ovarian cancer. Proc. Natl. Acad. Sci. USA 2001, 98, 1176-1181. [CrossRef]

19. Narkiewicz, J.; Klasa-Mazurkiewicz, D.; Zurawa-Janicka, D.; Skorko-Glonek, J.; Emerich, J.; Lipinska, B. Changes in mRNA and protein levels of human HtrA1, HtrA2 and HtrA3 in ovarian cancer. Clin. Biochem. 2008, 41, 561-569. [CrossRef]

20. Narkiewicz, J.; Lapinska-Szumczyk, S.; Zurawa-Janicka, D.; Skorko-Glonek, J.; Emerich, J.; Lipinska, B. Expression of human HtrA1, HtrA2, HtrA3 and TGF-beta1 genes in primary endometrial cancer. Oncol. Rep. 2009, 21, 1529-1537.

21. Lorenzi, T.; Marzioni, D.; Giannubilo, S.; Quaranta, A.; Crescimanno, C.; De Luca, A.; Baldi, A.; Todros, T.; Tranquilli, A.L.; Castellucci, M. Expression patterns of two serine protease HtrA1 forms in human placentas complicated by preeclampsia with and without intrauterine growth restriction. Placenta 2009, 30, 35-40. [CrossRef] [PubMed]

22. Li, Y.; Puryer, M.; Lin, E.; Hale, K.; Salamonsen, L.A.; Manuelpillai, U.; Tong, S.; Chan, W.; Wallace, E.M.; Nie, G. Placental HtrA3 is regulated by oxygen tension and serum levels are altered during early pregnancy in women destined to develop preeclampsia. J. Clin. Endocrinol. Metab. 2011, 96, 403-411. [CrossRef] [PubMed]

23. Teoh, S.S.; Zhao, M.; Wang, Y.; Chen, Q.; Nie, G. Serum HtrA1 is differentially regulated between early-onset and late-onset preeclampsia. Placenta 2015, 36, 990-995. [CrossRef] [PubMed]

24. Singh, H.; Zhao, M.; Chen, Q.; Wang, Y.; Li, Y.; Kaitu'u-Lino, T.J.; Tong, S.; Nie, G. Human HtrA4 Expression Is Restricted to the Placenta, Is Significantly Up-Regulated in Early-Onset Preeclampsia, and High Levels of HtrA4 Cause Endothelial Dysfunction. J. Clin. Endocrinol. Metab. 2015, 100, E936-E945. [CrossRef]

25. Singh, H.; Nero, T.L.; Wang, Y.; Parker, M.W.; Nie, G. Activity-modulating monoclonal antibodies to the human serine protease HtrA3 provide novel insights into regulating HtrA proteolytic activities. PLoS ONE 2014, 9, e108235. [CrossRef]

26. Nie, G.Y.; Hampton, A.; Li, Y.; Findlay, J.K.; Salamonsen, L.A. Identification and cloning of two isoforms of human hightemperature requirement factor A3 (HtrA3), characterization of its genomic structure and comparison of its tissue distribution with HtrA1 and HtrA2. Biochem. J. 2003, 371 Pt 1, 39-48. [CrossRef] [PubMed]

27. Nie, G.Y.; Li, Y.; Minoura, H.; Batten, L.; Ooi, G.T.; Findlay, J.K.; Salamonsen, L.A. A novel serine protease of the mammalian HtrA family is up-regulated in mouse uterus coinciding with placentation. Mol. Hum. Reprod. 2003, 9, 279-290. [CrossRef]

28. Bowden, M.; Drummond, A.E.; Salamonsen, L.A.; Findlay, J.K.; Nie, G. Evolutionary conservation of mammalian HTRA3 and its developmental regulation in the rat ovary. J. Exp. Zool. Part B Mol. Dev. Evol. 2009, 312, 701-713. [CrossRef] [PubMed]

29. Eigenbrot, C.; Ultsch, M.; Lipari, M.T.; Moran, P.; Lin, S.J.; Ganesan, R.; Quan, C.; Tom, J.; Sandoval, W.; van Lookeren Campagne, M.; et al. Structural and functional analysis of HtrA1 and its subdomains. Structure 2012, 20, 1040-1050. [CrossRef]

30. De Luca, A.; De Falco, M.; Severino, A.; Campioni, M.; Santini, D.; Baldi, F.; Paggi, M.G.; Baldi, A. Distribution of the serine protease HtrA1 in normal human tissues. J. Histochem. Cytochem. Off. J. Histochem. Soc. 2003, 51, 1279-1284. [CrossRef]

31. De Luca, A.; De Falco, M.; Fedele, V.; Cobellis, L.; Mastrogiacomo, A.; Laforgia, V.; Tuduce, I.L.; Campioni, M.; Giraldi, D.; Paggi, M.G.; et al. The serine protease HtrA1 is upregulated in the human placenta during pregnancy. J. Histochem. Cytochem. Off. J. Histochem. Soc. 2004, 52, 885-892. [CrossRef] [PubMed] 
32. Nie, G.; Hale, K.; Li, Y.; Manuelpillai, U.; Wallace, E.M.; Salamonsen, L.A. Distinct expression and localization of serine protease HtrA1 in human endometrium and first-trimester placenta. Dev. Dyn. Off. Publ. Am. Assoc. Anat. 2006, 235, 3448-3455. [CrossRef]

33. Nie, G.; Li, Y.; Hale, K.; Okada, H.; Manuelpillai, U.; Wallace, E.M.; Salamonsen, L.A. Serine peptidase HTRA3 is closely associated with human placental development and is elevated in pregnancy serum. Biol. Reprod. 2006, 74, 366-374. [CrossRef]

34. Liu, J.; Li, Y.; Hoh, J. Generation and characterization of mice with a conditional null allele of the HtrA4 gene. Mol. Med. Rep. 2015, 12, 6768-6774. [CrossRef]

35. Inagaki, A.; Nishizawa, H.; Ota, S.; Suzuki, M.; Inuzuka, H.; Miyamura, H.; Sekiya, T.; Kurahashi, H.; Udagawa, Y. Upregulation of HtrA4 in the placentas of patients with severe pre-eclampsia. Placenta 2012, 33, 919-926. [CrossRef] [PubMed]

36. Wang, Y.; Nie, G. High levels of HtrA4 observed in preeclamptic circulation drastically alter endothelial gene expression and induce inflammation in human umbilical vein endothelial cells. Placenta 2016, 47, 46-55. [CrossRef] [PubMed]

37. Liu, C.; Xing, F.; He, Y.; Zong, S.; Luo, C.; Li, C.; Duan, T.; Wang, K.; Zhou, Q. Elevated HTRA1 and HTRA4 in severe preeclampsia and their roles in trophoblast functions. Mol. Med. Rep. 2018, 18, 2937-2944. [CrossRef]

38. Wang, Y.; Lim, R.; Nie, G. HtrA4 may play a major role in inhibiting endothelial repair in pregnancy complication preeclampsia. Sci. Rep. 2019, 9, 2728. [CrossRef] [PubMed]

39. Wang, Y.; La, M.; Pham, T.; Lovrecz, G.O.; Nie, G. High levels of HtrA4 detected in preeclamptic circulation may disrupt endothelial cell function by cleaving the main VEGFA receptor KDR. FASEB J. 2019, 33, 5058-5066. [CrossRef]

40. Tseng, E.; Yee Teoh, S.S.; Wang, Y.; Nie, G. Elevated protease HtrA4 in the maternal circulation of preeclampsia may contribute to endothelial barrier disruption by cleaving key junctional protein VE-cadherin. Placenta 2019, 76, 51-53. [CrossRef] [PubMed]

41. Zumbrunn, J.; Trueb, B. Primary structure of a putative serine protease specific for IGF-binding proteins. FEBS Lett. 1996, 398, 187-192. [CrossRef]

42. Clawson, G.A.; Bui, V.; Xin, P.; Wang, N.; Pan, W. Intracellular localization of the tumor suppressor HtrA1/Prss11 and its association with HPV16 E6 and E7 proteins. J. Cell. Biochem. 2008, 105, 81-88. [CrossRef] [PubMed]

43. Grau, S.; Baldi, A.; Bussani, R.; Tian, X.; Stefanescu, R.; Przybylski, M.; Richards, P.; Jones, S.A.; Shridhar, V.; Clausen, T.; et al. Implications of the serine protease HtrA1 in amyloid precursor protein processing. Proc. Natl. Acad. Sci. USA 2005, 102, 6021-6026. [CrossRef]

44. Grau, S.; Richards, P.J.; Kerr, B.; Hughes, C.; Caterson, B.; Williams, A.S.; Junker, U.; Jones, S.A.; Clausen, T.; Ehrmann, M. The role of human HtrA1 in arthritic disease. J. Biol. Chem. 2006, 281, 6124-6129. [CrossRef] [PubMed]

45. Yang, Z.; Camp, N.J.; Sun, H.; Tong, Z.; Gibbs, D.; Cameron, D.J.; Chen, H.; Zhao, Y.; Pearson, E.; Li, X.; et al. A variant of the HTRA1 gene increases susceptibility to age-related macular degeneration. Science 2006, 314, 992-993. [CrossRef]

46. Hara, K.; Shiga, A.; Fukutake, T.; Nozaki, H.; Miyashita, A.; Yokoseki, A.; Kawata, H.; Koyama, A.; Arima, K.; Takahashi, T.; et al. Association of HTRA1 mutations and familial ischemic cerebral small-vessel disease. N. Engl. J. Med. 2009, 360, 1729-1739. [CrossRef]

47. Tiaden, A.N.; Richards, P.J. The emerging roles of HTRA1 in musculoskeletal disease. Am. J. Pathol. 2013, 182, 1482-1488 [CrossRef] [PubMed]

48. Truebestein, L.; Tennstaedt, A.; Monig, T.; Krojer, T.; Canellas, F.; Kaiser, M.; Clausen, T.; Ehrmann, M. Substrate-induced remodeling of the active site regulates human HTRA1 activity. Nat. Struct. Mol. Biol. 2011, 18, 386-388. [CrossRef]

49. Runyon, S.T.; Zhang, Y.; Appleton, B.A.; Sazinsky, S.L.; Wu, P.; Pan, B.; Wiesmann, C.; Skelton, N.J.; Sidhu, S.S. Structural and functional analysis of the PDZ domains of human HtrA1 and HtrA3. Protein Sci. 2007, 16, 2454-2471. [CrossRef]

50. Murwantoko; Yano, M.; Ueta, Y.; Murasaki, A.; Kanda, H.; Oka, C.; Kawaichi, M. Binding of proteins to the PDZ domain regulates proteolytic activity of HtrA1 serine protease. Biochem. J. 2004, 381 Pt 3, 895-904. [CrossRef]

51. Oka, C.; Tsujimoto, R.; Kajikawa, M.; Koshiba-Takeuchi, K.; Ina, J.; Yano, M.; Tsuchiya, A.; Ueta, Y.; Soma, A.; Kanda, H.; et al. HtrA1 serine protease inhibits signaling mediated by Tgfbeta family proteins. Development 2004, 131, 1041-1053. [CrossRef]

52. Lin, M.K.; Yang, J.; Hsu, C.W.; Gore, A.; Bassuk, A.G.; Brown, L.M.; Colligan, R.; Sengillo, J.D.; Mahajan, V.B.; Tsang, S.H. HTRA1, an age-related macular degeneration protease, processes extracellular matrix proteins EFEMP1 and TSP1. Aging Cell 2018, 17, e12710. [CrossRef] [PubMed]

53. Vierkotten, S.; Muether, P.S.; Fauser, S. Overexpression of HTRA1 leads to ultrastructural changes in the elastic layer of Bruch's membrane via cleavage of extracellular matrix components. PLoS ONE 2011, 6, e22959. [CrossRef] [PubMed]

54. Beaufort, N.; Scharrer, E.; Kremmer, E.; Lux, V.; Ehrmann, M.; Huber, R.; Houlden, H.; Werring, D.; Haffner, C.; Dichgans, M. Cerebral small vessel disease-related protease HtrA1 processes latent TGF-beta binding protein 1 and facilitates TGF-beta signaling. Proc. Natl. Acad. Sci. USA 2014, 111, 16496-16501. [CrossRef]

55. Yu, Z.; Cao, S.; Wu, A.; Yue, H.; Zhang, C.; Wang, J.; Xia, M.; Wu, J. Genetically Confirmed CARASIL: Case Report with Novel HTRA1 Mutation and Literature Review. World Neurosurg. 2020, 143, 121-128. [CrossRef] [PubMed]

56. Graham, J.R.; Chamberland, A.; Lin, Q.; Li, X.J.; Dai, D.; Zeng, W.; Ryan, M.S.; Rivera-Bermudez, M.A.; Flannery, C.R.; Yang, Z. Serine protease HTRA1 antagonizes transforming growth factor-beta signaling by cleaving its receptors and loss of HTRA1 in vivo enhances bone formation. PLoS ONE 2013, 8, e74094. [CrossRef]

57. Tennstaedt, A.; Popsel, S.; Truebestein, L.; Hauske, P.; Brockmann, A.; Schmidt, N.; Irle, I.; Sacca, B.; Niemeyer, C.M.; Brandt, R.; et al. Human high temperature requirement serine protease A1 (HTRA1) degrades tau protein aggregates. J. Biol. Chem. 2012, 287, 20931-20941. [CrossRef] 
58. He, X.; Khurana, A.; Maguire, J.L.; Chien, J.; Shridhar, V. HtrA1 sensitizes ovarian cancer cells to cisplatin-induced cytotoxicity by targeting XIAP for degradation. Int. J. Cancer 2012, 130, 1029-1035. [CrossRef]

59. Chien, J.; Ota, T.; Aletti, G.; Shridhar, R.; Boccellino, M.; Quagliuolo, L.; Baldi, A.; Shridhar, V. Serine protease HtrA1 associates with microtubules and inhibits cell migration. Mol. Cell Biol. 2009, 29, 4177-4187. [CrossRef]

60. Ajayi, F.; Kongoasa, N.; Gaffey, T.; Asmann, Y.W.; Watson, W.J.; Baldi, A.; Lala, P.; Shridhar, V.; Brost, B.; Chien, J. Elevated expression of serine protease HtrA1 in preeclampsia and its role in trophoblast cell migration and invasion. Am. J. Obstet. Gynecol. 2008, 199, 557.e1-557.e10. [CrossRef]

61. Moisoi, N.; Klupsch, K.; Fedele, V.; East, P.; Sharma, S.; Renton, A.; Plun-Favreau, H.; Edwards, R.E.; Teismann, P.; Esposti, M.D.; et al. Mitochondrial dysfunction triggered by loss of HtrA2 results in the activation of a brain-specific transcriptional stress response. Cell Death Differ. 2009, 16, 449-464. [CrossRef]

62. Jones, J.M.; Datta, P.; Srinivasula, S.M.; Ji, W.; Gupta, S.; Zhang, Z.; Davies, E.; Hajnoczky, G.; Saunders, T.L.; Van Keuren, M.L.; et al. Loss of Omi mitochondrial protease activity causes the neuromuscular disorder of mnd2 mutant mice. Nature 2003, 425, 721-727. [CrossRef]

63. Park, H.J.; Kim, S.S.; Seong, Y.M.; Kim, K.H.; Goo, H.G.; Yoon, E.J.; Do, S.M.; Kang, S.; Rhim, H. Beta-amyloid precursor protein is a direct cleavage target of HtrA2 serine protease. Implications for the physiological function of HtrA2 in the mitochondria. J. Biol. Chem. 2006, 281, 34277-34287. [CrossRef] [PubMed]

64. Suzuki, Y.; Imai, Y.; Nakayama, H.; Takahashi, K.; Takio, K.; Takahashi, R. A serine protease, HtrA2, is released from the mitochondria and interacts with XIAP, inducing cell death. Mol. Cell 2001, 8, 613-621. [CrossRef]

65. Verhagen, A.M.; Silke, J.; Ekert, P.G.; Pakusch, M.; Kaufmann, H.; Connolly, L.M.; Day, C.L.; Tikoo, A.; Burke, R.; Wrobel, C.; et al. HtrA2 promotes cell death through its serine protease activity and its ability to antagonize inhibitor of apoptosis proteins. J. Biol. Chem. 2002, 277, 445-454. [CrossRef]

66. Cilenti, L.; Soundarapandian, M.M.; Kyriazis, G.A.; Stratico, V.; Singh, S.; Gupta, S.; Bonventre, J.V.; Alnemri, E.S.; Zervos, A.S. Regulation of HAX-1 anti-apoptotic protein by Omi/HtrA2 protease during cell death. J. Biol. Chem. 2004, 279, 50295-50301. [CrossRef]

67. Trencia, A.; Fiory, F.; Maitan, M.A.; Vito, P.; Barbagallo, A.P.; Perfetti, A.; Miele, C.; Ungaro, P.; Oriente, F.; Cilenti, L.; et al. Omi/HtrA2 promotes cell death by binding and degrading the anti-apoptotic protein ped/pea-15. J. Biol. Chem. 2004, 279, 46566-46572. [CrossRef] [PubMed]

68. Chien, J. WT1 as a substrate of HtrA2: A potential pathway for therapeutic targeting by HtrA proteases. Future Oncol. 2010, 6, 1233-1235. [CrossRef]

69. Hartkamp, J.; Carpenter, B.; Roberts, S.G. The Wilms' tumor suppressor protein WT1 is processed by the serine protease HtrA2/Omi. Mol. Cell 2010, 37, 159-171. [CrossRef]

70. Tocharus, J.; Tsuchiya, A.; Kajikawa, M.; Ueta, Y.; Oka, C.; Kawaichi, M. Developmentally regulated expression of mouse HtrA3 and its role as an inhibitor of TGF-beta signaling. Dev. Growth Differ. 2004, 46, 257-274. [CrossRef]

71. Wenta, T.; Zurawa-Janicka, D.; Rychlowski, M.; Jarzab, M.; Glaza, P.; Lipinska, A.; Bienkowska-Szewczyk, K.; HermanAntosiewicz, A.; Skorko-Glonek, J.; Lipinska, B. HtrA3 is a cellular partner of cytoskeleton proteins and TCP1alpha chaperonin. J. Proteom. 2018, 177, 88-111. [CrossRef] [PubMed]

72. Wenta, T.; Rychlowski, M.; Jurewicz, E.; Jarzab, M.; Zurawa-Janicka, D.; Filipek, A.; Lipinska, B. The HtrA3 protease promotes drug-induced death of lung cancer cells by cleavage of the X-linked inhibitor of apoptosis protein (XIAP). FEBS J. 2019, 286, 4579-4596. [CrossRef] [PubMed]

73. Dynon, K.; Heng, S.; Puryer, M.; Li, Y.; Walton, K.; Endo, Y.; Nie, G. HtrA3 as an early marker for preeclampsia: Specific monoclonal antibodies and sensitive high-throughput assays for serum screening. PLoS ONE 2012, 7, e45956. [CrossRef] [PubMed]

74. Wang, L.-J.; Cheong, M.-L.; Lee, Y.-S.; Lee, M.-T.; Chen, H. High-temperature requirement protein A4 (HtrA4) suppresses the fusogenic activity of syncytin-1 and promotes trophoblast invasion. Mol. Cell. Biol. 2012, 32, 3707-3717. [CrossRef] [PubMed]

75. Vande Walle, L.; Lamkanfi, M.; Vandenabeele, P. The mitochondrial serine protease HtrA2/Omi: An overview. Cell Death Differ. 2008, 15, 453-460. [CrossRef]

76. Bogaerts, V.; Nuytemans, K.; Reumers, J.; Pals, P.; Engelborghs, S.; Pickut, B.; Corsmit, E.; Peeters, K.; Schymkowitz, J.; De Deyn, P.P.; et al. Genetic variability in the mitochondrial serine protease HTRA2 contributes to risk for Parkinson disease. Hum. Mutat. 2008, 29, 832-840. [CrossRef]

77. Kruger, R.; Sharma, M.; Riess, O.; Gasser, T.; Van Broeckhoven, C.; Theuns, J.; Aasly, J.; Annesi, G.; Bentivoglio, A.R.; Brice, A.; et al. A large-scale genetic association study to evaluate the contribution of Omi/HtrA2 (PARK13) to Parkinson's disease. Neurobiol. Aging 2011, 32, 548.e9-548.e18. [CrossRef]

78. Gray, C.W.; Ward, R.V.; Karran, E.; Turconi, S.; Rowles, A.; Viglienghi, D.; Southan, C.; Barton, A.; Fantom, K.G.; West, A.; et al Characterization of human HtrA2, a novel serine protease involved in the mammalian cellular stress response. Eur. J. Biochem. 2000, 267, 5699-5710. [CrossRef]

79. Cilenti, L.; Kyriazis, G.A.; Soundarapandian, M.M.; Stratico, V.; Yerkes, A.; Park, K.M.; Sheridan, A.M.; Alnemri, E.S.; Bonventre, J.V.; Zervos, A.S. Omi/HtrA2 protease mediates cisplatin-induced cell death in renal cells. Am. J. Physiol. Ren. Physiol. 2005, 288, F371-F379. [CrossRef] 
80. Beleford, D.; Rattan, R.; Chien, J.; Shridhar, V. High temperature requirement A3 (HtrA3) promotes etoposide- and cisplatininduced cytotoxicity in lung cancer cell lines. J. Biol. Chem. 2010, 285, 12011-12027. [CrossRef]

81. Glaza, P.; Osipiuk, J.; Wenta, T.; Zurawa-Janicka, D.; Jarzab, M.; Lesner, A.; Banecki, B.; Skorko-Glonek, J.; Joachimiak, A.; Lipinska, B. Structural and Functional Analysis of Human HtrA3 Protease and Its Subdomains. PLoS ONE 2015, 10, e0131142. [CrossRef] [PubMed]

82. Singh, H.; Makino, S.; Endo, Y.; Li, Y.; Stephens, A.N.; Nie, G. Application of the wheat-germ cell-free translation system to produce high temperature requirement A3 (HtrA3) proteases. BioTechniques 2012, 52, 23-28. [CrossRef] [PubMed]

83. Chen, Y.Y.; Chuang, P.Y.; Chen, C.P.; Chiu, Y.H.; Lo, H.F.; Cheong, M.L.; Huang, J.Y.; Kuo, P.L.; Chen, H. Functional antagonism between high temperature requirement protein A (HtrA) family members regulates trophoblast invasion. J. Biol. Chem. 2014, 289, 22958-22968. [CrossRef] [PubMed]

84. Damsky, C.H.; Librach, C.; Lim, K.H.; Fitzgerald, M.L.; McMaster, M.T.; Janatpour, M.; Zhou, Y.; Logan, S.K.; Fisher, S.J. Integrin switching regulates normal trophoblast invasion. Development 1994, 120, 3657-3666. [CrossRef]

85. Chiu, Y.H.; Chen, H. GATA3 inhibits GCM1 activity and trophoblast cell invasion. Sci. Rep. 2016, 6, 21630. [CrossRef] [PubMed]

86. Mansilla, M.; Wang, Y.; Lim, R.; Palmer, K.; Nie, G. HtrA4 is up-regulated during trophoblast syncytialization and BeWo cells fail to syncytialize without HtrA4. Sci. Rep. 2021, 11, 14363. [CrossRef]

87. Wang, Y.; Chen, Q.; Zhao, M.; Walton, K.; Harrison, C.; Nie, G. Multiple Soluble TGF-beta Receptors in Addition to Soluble Endoglin Are Elevated in Preeclamptic Serum and They Synergistically Inhibit TGF-beta Signaling. J. Clin. Endocrinol. Metab. 2017, 102, 3065-3074. [CrossRef]

88. Wenta, T.; Rychlowski, M.; Jarzab, M.; Lipinska, B. HtrA4 Protease Promotes Chemotherapeutic-Dependent Cancer Cell Death. Cells 2019, 8, 1112. [CrossRef]

89. Kummari, R.; Dutta, S.; Chaganti, L.K.; Bose, K. Discerning the mechanism of action of HtrA4: A serine protease implicated in the cell death pathway. Biochem. J. 2019, 476, 1445-1463. [CrossRef]

90. Wenta, T.; Jarzab, M.; Rychlowski, M.; Borysiak, M.; Latala, A.; Zurawa-Janicka, D.; Filipek, A.; Lipinska, B. Cellular substrates and pro-apoptotic function of the human HtrA4 protease. J. Proteom. 2019, 209, 103505. [CrossRef]

91. Chien, J.; Campioni, M.; Shridhar, V.; Baldi, A. HtrA serine proteases as potential therapeutic targets in cancer. Curr. Cancer Drug Targets 2009, 9, 451-468. [CrossRef] [PubMed]

92. Chien, J.; Staub, J.; Hu, S.I.; Erickson-Johnson, M.R.; Couch, F.J.; Smith, D.I.; Crowl, R.M.; Kaufmann, S.H.; Shridhar, V. A candidate tumor suppressor HtrA1 is downregulated in ovarian cancer. Oncogene 2004, 23, 1636-1644. [CrossRef]

93. Baldi, A.; De Luca, A.; Morini, M.; Battista, T.; Felsani, A.; Baldi, F.; Catricala, C.; Amantea, A.; Noonan, D.M.; Albini, A.; et al. The HtrA1 serine protease is down-regulated during human melanoma progression and represses growth of metastatic melanoma cells. Oncogene 2002, 21, 6684-6688. [CrossRef]

94. Sotiriou, C.; Wirapati, P.; Loi, S.; Harris, A.; Fox, S.; Smeds, J.; Nordgren, H.; Farmer, P.; Praz, V.; Haibe-Kains, B.; et al. Gene expression profiling in breast cancer: Understanding the molecular basis of histologic grade to improve prognosis. J. Natl. Cancer Inst. 2006, 98, 262-272. [CrossRef] [PubMed]

95. Welsh, J.B.; Sapinoso, L.M.; Su, A.I.; Kern, S.G.; Wang-Rodriguez, J.; Moskaluk, C.A.; Frierson, H.F., Jr.; Hampton, G.M. Analysis of gene expression identifies candidate markers and pharmacological targets in prostate cancer. Cancer Res. 2001, 61, 5974-5978. [PubMed]

96. Esposito, V.; Campioni, M.; De Luca, A.; Spugnini, E.P.; Baldi, F.; Cassandro, R.; Mancini, A.; Vincenzi, B.; Groeger, A.; Caputi, M.; et al. Analysis of HtrA1 serine protease expression in human lung cancer. Anticancer Res. 2006, 26, 3455-3459.

97. Mullany, S.A.; Moslemi-Kebria, M.; Rattan, R.; Khurana, A.; Clayton, A.; Ota, T.; Mariani, A.; Podratz, K.C.; Chien, J.; Shridhar, V. Expression and functional significance of HtrA1 loss in endometrial cancer. Clin. Cancer Res. 2011, 17, 427-436. [CrossRef] [PubMed]

98. He, X.; Ota, T.; Liu, P.; Su, C.; Chien, J.; Shridhar, V. Downregulation of HtrA1 promotes resistance to anoikis and peritoneal dissemination of ovarian cancer cells. Cancer Res. 2010, 70, 3109-3118. [CrossRef] [PubMed]

99. Chien, J.; Aletti, G.; Baldi, A.; Catalano, V.; Muretto, P.; Keeney, G.L.; Kalli, K.R.; Staub, J.; Ehrmann, M.; Cliby, W.A.; et al. Serine protease HtrA1 modulates chemotherapy-induced cytotoxicity. J. Clin. Investig. 2006, 116, 1994-2004. [CrossRef] [PubMed]

100. Wang, L.; Diao, Y.-C.; Jiao, J.-W.; Wang, C.; Yu, J.; Li, B.; Dai, S.-Z. HtrA2/Omi protease in epithelial ovarian carcinoma: Clinical significance and antineoplastic efficacy of its overexpression on subcutaneous transplanted tumor in nude mice model. Int. J. Clin. Exp. Patho. 2016, 9, 3161-3169.

101. Soyama, H.; Miyamoto, M.; Takano, M.; Aoyama, T.; Matsuura, H.; Sakamoto, T.; Takasaki, K.; Kuwahara, M.; Kato, K.; Yoshikawa, T.; et al. Ovarian serous carcinomas acquire cisplatin resistance and increased invasion through downregulation of the high-temperature-required protein A2 (HtrA2), following repeated treatment with cisplatin. Med. Oncol. 2017, 34, 201. [CrossRef] [PubMed]

102. Hu, X.; Chen, X.; Ping, H.; Chen, Z.; Zeng, F.; Lu, G. Immunohistochemical analysis of Omi/HtrA2 expression in prostate cancer and benign prostatic hyperplasia. J. Huazhong Univ. Sci. Technology. Med. Sci. Hua Zhong Ke Ji Da Xue Xue Bao Yi Xue Ying De Wen Ban Huazhong Keji Daxue Xuebao Yixue Yingdewen Ban 2005, 25, 671-673. [CrossRef]

103. Lee, S.H.; Lee, J.W.; Kim, H.S.; Kim, S.Y.; Park, W.S.; Kim, S.H.; Lee, J.Y.; Yoo, N.J. Immunohistochemical analysis of Omi/HtrA2 expression in stomach cancer. APMIS Acta Pathol. Microbiol. Immunol. Scand. 2003, 111, 586-590. [CrossRef] 
104. Dhanasekaran, S.M.; Barrette, T.R.; Ghosh, D.; Shah, R.; Varambally, S.; Kurachi, K.; Pienta, K.J.; Rubin, M.A.; Chinnaiyan, A.M. Delineation of prognostic biomarkers in prostate cancer. Nature 2001, 412, 822-826. [CrossRef]

105. Sorlie, T.; Tibshirani, R.; Parker, J.; Hastie, T.; Marron, J.S.; Nobel, A.; Deng, S.; Johnsen, H.; Pesich, R.; Geisler, S.; et al. Repeated observation of breast tumor subtypes in independent gene expression data sets. Proc. Natl. Acad. Sci. USA 2003, 100, 8418-8423. [CrossRef]

106. Bowden, M.A.; Drummond, A.E.; Fuller, P.J.; Salamonsen, L.A.; Findlay, J.K.; Nie, G. High-temperature requirement factor A3 (Htra3): A novel serine protease and its potential role in ovarian function and ovarian cancers. Mol. Cell. Endocrinol. 2010, 327, 13-18. [CrossRef]

107. Zhao, M.; Ding, J.X.; Nie, G.Y.; Wei, J.; Li, Y.; Yin, X.Y.; Chen, Q. HTRA3 is reduced in ovarian cancers regardless of stage. Cancer Investig. 2014, 32, 464-469. [CrossRef] [PubMed]

108. Singh, H.; Li, Y.; Fuller, P.J.; Harrison, C.; Rao, J.; Stephens, A.N.; Nie, G. HtrA3 Is Downregulated in Cancer Cell Lines and Significantly Reduced in Primary Serous and Granulosa Cell Ovarian Tumors. J. Cancer 2013, 4, 152-164. [CrossRef]

109. Bowden, M.A.; Di Nezza-Cossens, L.A.; Jobling, T.; Salamonsen, L.A.; Nie, G. Serine proteases HTRA1 and HTRA3 are downregulated with increasing grades of human endometrial cancer. Gynecol. Oncol. 2006, 103, 253-260. [CrossRef] [PubMed]

110. Lv, Q.; Yang, B.; Ning, C.; Xie, B.; Nie, G.; Chen, X.; Chen, Q. Hypoxia is involved in the reduction of HtrA3 in patients with endometrial hyperplasia and cancer. Biochem. Biophys. Res. Commun. 2018, 503, 2918-2923. [CrossRef] [PubMed]

111. Yin, Y.; Wu, M.; Nie, G.; Wang, K.; Wei, J.; Zhao, M.; Chen, Q. HtrA3 is negatively correlated with lymph node metastasis in invasive ductal breast cancer. Tumour Biol. J. Int. Soc. Oncodevelopmental Biol. Med. 2013, 34, 3611-3617. [CrossRef]

112. Beleford, D.; Liu, Z.; Rattan, R.; Quagliuolo, L.; Boccellino, M.; Baldi, A.; Maguire, J.; Staub, J.; Molina, J.; Shridhar, V. Methylation induced gene silencing of HtrA3 in smoking-related lung cancer. Clin. Cancer Res. Off. J. Am. Assoc. Cancer Res. 2010, 16, 398-409. [CrossRef] [PubMed]

113. Zhao, J.; Zhang, J.; Zhang, X.; Feng, M.; Qu, J. High temperature requirement A3 (HTRA3) expression predicts postoperative recurrence and survival in patients with non-small-cell lung cancer. Oncotarget 2016, 7, 40725-40734. [CrossRef]

114. Hao, Y.; Triadafilopoulos, G.; Sahbaie, P.; Young, H.S.; Omary, M.B.; Lowe, A.W. Gene expression profiling reveals stromal genes expressed in common between Barrett's esophagus and adenocarcinoma. Gastroenterology 2006, 131, 925-933. [CrossRef]

115. Iacobuzio-Donahue, C.A.; Maitra, A.; Olsen, M.; Lowe, A.W.; van Heek, N.T.; Rosty, C.; Walter, K.; Sato, N.; Parker, A.; Ashfaq, R.; et al. Exploration of global gene expression patterns in pancreatic adenocarcinoma using cDNA microarrays. Am. J. Pathol. 2003, 162, 1151-1162. [CrossRef]

116. Korkola, J.E.; Houldsworth, J.; Chadalavada, R.S.; Olshen, A.B.; Dobrzynski, D.; Reuter, V.E.; Bosl, G.J.; Chaganti, R.S. Downregulation of stem cell genes, including those in a $200-\mathrm{kb}$ gene cluster at $12 \mathrm{p} 13.31$, is associated with in vivo differentiation of human male germ cell tumors. Cancer Res. 2006, 66, 820-827. [CrossRef]

117. Andersson, A.; Ritz, C.; Lindgren, D.; Eden, P.; Lassen, C.; Heldrup, J.; Olofsson, T.; Rade, J.; Fontes, M.; Porwit-Macdonald, A.; et al. Microarray-based classification of a consecutive series of 121 childhood acute leukemias: Prediction of leukemic and genetic subtype as well as of minimal residual disease status. Leukemia 2007, 21, 1198-1203. [CrossRef] [PubMed]

118. van't Veer, L.J.; Dai, H.; van de Vijver, M.J.; He, Y.D.; Hart, A.A.; Mao, M.; Peterse, H.L.; van der Kooy, K.; Marton, M.J.; Witteveen, A.T.; et al. Gene expression profiling predicts clinical outcome of breast cancer. Nature 2002, 415, 530-536. [CrossRef]

119. Baldi, A.; Mottolese, M.; Vincenzi, B.; Campioni, M.; Mellone, P.; Di Marino, M.; di Crescenzo, V.G.; Visca, P.; Menegozzo, S.; Spugnini, E.P.; et al. The serine protease HtrA1 is a novel prognostic factor for human mesothelioma. Pharmacogenomics 2008, 9 , 1069-1077. [CrossRef] [PubMed]

120. Hasan, M.Z.; Ikawati, M.; Tocharus, J.; Kawaichi, M.; Oka, C. Abnormal development of placenta in HtrA1-deficient mice. Dev. Biol. 2015, 397, 89-102. [CrossRef] [PubMed]

121. Nie, G.; Li, Y.; Salamonsen, L.A. Serine protease HtrA1 is developmentally regulated in trophoblast and uterine decidual cells during placental formation in the mouse. Dev. Dyn. 2005, 233, 1102-1109. [CrossRef]

122. Zong, L.; Wang, L.; Huang, P.; Shao, W.; Song, Y.; Gou, W. High temperature requirement A1 in placental tissues and serum from pre-eclamptic pregnancies with or without fetal growth restriction. Arch. Med. Sci. AMS 2013, 9, 690-696. [CrossRef]

123. Skinner, S.; Rolnik, D.L.; Wang, Y.; Nie, G.; Syngelaki, A.; Nicolaides, K.H.; da Silva Costa, F. Second and third trimester serum levels of HtrA1 in pregnancies affected by pre-eclampsia. Placenta 2021, 106, 1-6. [CrossRef]

124. Bowden, M.A.; Li, Y.; Liu, Y.X.; Findlay, J.K.; Salamonsen, L.A.; Nie, G. HTRA3 expression in non-pregnant rhesus monkey ovary and endometrium, and at the maternal-fetal interface during early pregnancy. Reprod. Biol. Endocrinol. RBE 2008, 6, 22. [CrossRef] [PubMed]

125. Nie, G.; Li, Y.; He, H.; Findlay, J.K.; Salamonsen, L.A. HtrA3, a serine protease possessing an IGF-binding domain, is selectively expressed at the maternal-fetal interface during placentation in the mouse. Placenta 2006, 27, 491-501. [CrossRef]

126. Singh, H.; Makino, S.I.; Endo, Y.; Nie, G. Inhibition of HTRA3 stimulates trophoblast invasion during human placental development. Placenta 2010, 31, 1085-1092. [CrossRef]

127. Singh, H.; Endo, Y.; Nie, G. Decidual HtrA3 negatively regulates trophoblast invasion during human placentation. Hum. Reprod. 2011, 26, 748-757. [CrossRef]

128. Li, Y.; Salamonsen, L.A.; Hyett, J.; Costa, F.D.S.; Nie, G. Maternal HtrA3 optimizes placental development to influence offspring birth weight and subsequent white fat gain in adulthood. Sci. Rep. 2017, 7, 4627. [CrossRef] [PubMed] 
129. Teoh, S.S.Y.; Wang, Y.; Li, Y.; Leemaqz, S.Y.; Dekker, G.A.; Roberts, C.T.; Nie, G. Low Serum Levels of HtrA3 at 15 Weeks of Gestation Are Associated with Late-Onset Preeclampsia Development and Small for Gestational Age Birth. Fetal Diagn. Ther. 2019, 46, 392-401. [CrossRef] [PubMed]

130. Wang, Y.; Li, Y.; Hyett, J.; da Silva Costa, F.; Nie, G. HtrA3 Isoform-Specific ELISAs for Early Detection of Preeclampsia. J. Biomol. Screen. 2016, 23, 1092-1099. [CrossRef]

131. Nishizawa, H.; Ota, S.; Suzuki, M.; Kato, T.; Sekiya, T.; Kurahashi, H.; Udagawa, Y. Comparative gene expression profiling of placentas from patients with severe pre-eclampsia and unexplained fetal growth restriction. Reprod. Biol. Endocrinol. RBE 2011, 9 , 107. [CrossRef]

132. Lapaire, O.; Grill, S.; Lalevee, S.; Kolla, V.; Hosli, I.; Hahn, S. Microarray screening for novel preeclampsia biomarker candidates. Fetal Diagn. Ther. 2012, 31, 147-153. [CrossRef] [PubMed]

133. Kaartokallio, T.; Cervera, A.; Kyllonen, A.; Laivuori, K.; Kere, J.; Laivuori, H. Gene expression profiling of pre-eclamptic placentae by RNA sequencing. Sci. Rep. 2015, 5, 14107. [CrossRef] [PubMed]

134. Brew, O.; Sullivan, M.H.; Woodman, A. Comparison of Normal and Pre-Eclamptic Placental Gene Expression: A Systematic Review with Meta-Analysis. PLoS ONE 2016, 11, e0161504. [CrossRef] [PubMed]

135. Wang, Y.; Lim, R.; Nie, G. Elevated circulating HtrA4 in preeclampsia may alter endothelial expression of senescence genes. Placenta 2020, 90, 71-81. [CrossRef]

136. Wang, Y.; Gu, Y.; Granger, D.N.; Roberts, J.M.; Alexander, J.S. Endothelial junctional protein redistribution and increased monolayer permeability in human umbilical vein endothelial cells isolated during preeclampsia. Am. J. Obstet. Gynecol. 2002, 186, 214-220. [CrossRef]

137. Prochazka, M.; Prochazkova, J.; Lubusky, M.; Pilka, R.; Ulehlova, J.; Michalec, I.; Polak, P.; Kacerovsky, M.; Slavik, L. Markers of endothelial activation in preeclampsia. Clin. Lab. 2015, 61, 39-46. [CrossRef]

138. Rousseau, A.; Favier, R.; Van Dreden, P. Elevated circulating soluble thrombomodulin activity, tissue factor activity and circulating procoagulant phospholipids: New and useful markers for pre-eclampsia? Eur. J. Obstet. Gynecol. Reprod. Biol. 2009, 146, 46-49. [CrossRef]

139. Stenczer, B.; Molvarec, A.; Szabo, G.; Szarka, A.; Fugedi, G.; Szijarto, J.; Rigo, J., Jr. Circulating levels of thrombospondin-1 are decreased in HELLP syndrome. Thromb. Res. 2012, 129, 470-473. [CrossRef]

140. Steinmetz, M.; Nickenig, G.; Werner, N. Endothelial-regenerating cells: An expanding universe. Hypertension 2010, 55, 593-599. [CrossRef] 